\title{
Core Acquisition Management in Remanufacturing \\ - Current Status and Modeling Techniques
}

\author{
Shuoguo Wei
}

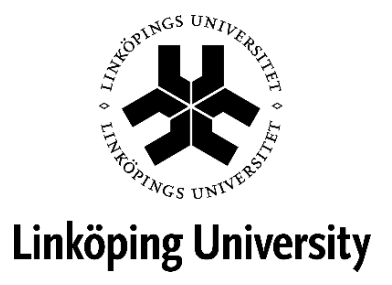

Division of Production Economics,

Department of Management and Engineering,

Linköping University, SE-581 83 Linköping, Sweden

Linköping [2014] 
(C) [Shuoguo Wei, 2014]

Printed in Sweden by [Liu Tryck, 2014]

Cover: Designed by Shuoguo Wei and Per Lagman

ISSN 0345-7524

ISBN 978-91-7519-167-6

Core Acquisition Management in Remanufacturing - Current Status and Modeling Techniques

By

Shuoguo Wei

December 2014

Linköping studies in science and technology. Dissertations, No. 1637

Division of Production Economics,

Department of Management and Engineering,

Linköping University

SE-581 83 Linköping, Sweden 


\begin{abstract}
Remanufacturing is an important product recovery option that benefits our sustainable development. Cores, i.e. the used products/parts, are essential resources for remanufacturing. Without cores, there will not be any remanufactured products. Challenges in the core acquisition process are mainly caused by the uncertainties of: return volume, timing and core quality. Core Acquisition Management actively attempts to reduce these uncertainties and achieve a better balance of demand and return for the remanufacturers. The aim of this dissertation is to extend the knowledge of Core Acquisition Management in remanufacturing, by investigating the current status of research and industrial practice, and developing quantitative models that assist the decision making in the core acquisition process.
\end{abstract}

In the dissertation, a literature review is firstly conducted to provide an overview about the current research in Core Acquisition Management. Possible further research interests, for example, more studies based on non-hybrid remanufacturing systems and imperfect substitution assumption are suggested. Through an industrial survey carried out in a fast developing remanufacturing market - China, environmental responsibility and ethical concerns, customer orientation and strategic advantage are identified as the most important motives for the remanufacturers, while customer recognition is their most serious barrier at present. Suggestions for further improving the Chinese remanufacturing industry from the policy-makers' perspective are provided. After the above investigation, mathematical models are then developed to assist the acquisition decisions in two aspects: to deal with the uncertainties of return volume and timing, and to deal with the uncertainties of core quality.

Acquisition decision about volume and timing is firstly studied from a product life cycle perspective, where the demands for remanufactured products and the core availability change over time. According to industrial observations, the remanufacturing cost decreases with respect to its core inventory. Using optimal control theory, core acquisition and remanufacturing decisions are derived to maximize the remanufacturer's profit. It is found that besides a simple bang-bang type control policy (either collecting as much as possible, or nothing), a special form of synchronizing policy (adjusting the core collection rate with demand rate) also exists. Furthermore, the acquisition decision depends greatly on the valuation of cores, and Real Option Valuation approaches are later used to capture the value of flexibility provided by owning cores when different aspects of remanufacturing environment are random. More specifically, the value of disposing a core earlier is investigated when the price of remanufactured product is uncertain, and the impact of the correlation between stochastic demand and return is also studied.

To deal with the uncertainties of core quality, refund policies with different numbers of quality classes are studied. Under the assumption of uniformly distributed quality, analytical solutions for these refund policies are derived. Numerical examples indicate that the customers' valuation of cores is an important factor influencing the return rates and the remanufacturer's profit. Refund policies with a small number of quality classes could already bring major advantages. Credit refund policies (without deposits) are included for comparisons. In addition, within a game theory framework, the trade-off of two types of errors of the quality inspection in a depositrefund policy is studied. The salvage values of different cores show great influences on the re- 
manufacturer's policy choices. The value of information transparency about the inspection errors are studied under different conditions. Interestingly, the customer may actually return more low quality cores when the inspection accuracy is improved.

Keywords: core acquisition, remanufacturing, closed-loop supply chain, quantitative modeling, return uncertainties 


\title{
Styrning av insamlandet av stommar för återtillverkning
}

- Nuvarande status och tekniker för modellering

\begin{abstract}
De huvudsakliga utmaningar av stommar för återtillverkning finns huvudsakligen utmaningar som berör osäkerheter för dess volymer, ankomst och kvalitet. Styrning av insamlandet av stommar handlar om att kunna hantera dessa osäkerheter genom olika aktiviteter. Den här doktorsavhandlingen har som mål att 1) beskriva nuvarande status inom forskning och industri, 2) utveckling av matematiska modeller för att stödja beslut vid stomminsamling.

I avhandlingen utfördes först en litteraturstudie för att ge en överblick om nuvarande forskning inom styrning av stomminsamling. Möjliga forskningsområden, till exempel, mer detaljerad analys av mekanismer för stomminsamling föreslås. Genom en industriell enkät utförd inom den snabbt växande återtillverkningsindustrin i Kina, identifierades "miljöansvar och etik", "kundorientering", "strategisk fördel" som de största motiven för återtillverkning medan "kunderkännande", "lagkrav" och "brist på säljkanaler" fanns bland de största hinder för återtillverkning. Förslag på hur man kan förbättra återtillverkningen i Kina föreslås från ett policyperspektiv. Efter undersökningarna av det vetenskapliga och industriella nuläget utvecklas matematiska modeller för att stödja beslut för insamling av stommar baserat på två aspekter; insamlingsvolymer och kvalitetsklassifikationsmetoder.
\end{abstract}

Beslut om insamlingsvolymer studeras först ur ett produktlivscykelperspektiv där efterfrågan på återtillverkade produkter och tillgången på stommar ändras över tiden. Enligt industriella observationer är återtillverkningskostnaderna avtagande med avseende på lagernivåer. Genom att använda sig av kontrollteori baseras beslut om stomminsamling och återtillverkning på att återtillverkarnas vinst ska maximeras. Resultaten visar att, förutom en enkel bang-bang policykontrolltyp (antingen samla in så mycket som möjligt, eller ingenting), existera även en speciell form av synkroniseringspolicy (justera graden av stomminsamling i takt med efterfrågan). Insamlingsbeslutet beror mycket på värderingen av stommar. En baserad på reala optioner metodik används för att fånga värdet av flexibilitet genom att äga stommar då olika aspekter av återtillverkningsproblemet är stokastiska. Mer specifikt undersöktes även värdet av att avyttra en stomme tidigare då priset av återtillverkade produkter var osäkert, samt påverkan av korrelationen mellan stokastisk efterfrågan och insamling.

När det gäller kvalitetklassificeringsmetoder kategoriseras återbäringspolicys enligt antalet kvalitetsklasser. Förutsatt en likformig fördelning av kvalitet bestäms analytiska lösningar till dessa återbäringspolicys. Numeriska exempel indikerar att kundernas värdering av stommar är en viktig faktor som påverkar graden av insamling och återtillverkarnas vinst. Redan för återbäringspolicys med ett fåtal antal kvalitetsklasser kan man få stora fördelar. Kreditåterbäringspolicys (utan pant) inkluderas för jämförelse. Med ett spelteoriramverk studeras avvägningen av två feltyper av kvalitetsinspektionen i en pantåterbäringspolicy. Värdet av tillvaratagandet för olika stommar påvisar stor påverkan på återtillverkarnas policyval. Värdet av informationstransparansen för inspektionsfel studeras under olika förhållanden. Intressant nog lämnar kunderna in fler stommar med låg kvalitet när inspektionsnoggrannheten förbättras.

Nyckelord: insamling av stommar, återtillverkning, modellering, returlogistik, returflöden 



\title{
Acknowledgements
}

It has been a precious experience for me working on such an interesting topic in remanufacturing area. Therefore I would like to firstly express my sincere thanks to Professor Ou Tang, who introduced me this subject, with a very beautiful country Sweden in the package. Furthermore, Professor Ou Tang has been endlessly supported me with his great patience and knowledge. His dedication to work, careful planning and self-discipline, have been set a very good model for me. It helps not only my research, but will also benefit a lot in the rest of my life.

My second supervisor Erik Sundin has also helped me a lot with his rich research knowledge and industrial experience in remanufacturing area. I especially like his passion in remanufacturing and his kind encouragement during my research. I would also like to express my thanks to Professor Jan Olhager, for his support as the second supervisor in the beginning of my research project. Professor Jiazhen Huo is the supervisor during my Master's study. I will not forget his kind help since I first time broke into his office and expressed my interest to do research that contributes to the industry.

During the last four and half years, I have been very luckily collaborated in my research with Weihua Liu, Dongbo Cheng, Nurmaya Musa and Daqin Wang. It was both very helpful and very fun to work with them. Besides, Professor Gunnar Aronsson introduced me optimal control theory. He kept working even after being retired and sick. Professor Robert Grubbström has also been very active after his retirement, whom I can always met in research conferences. Their enthusiasm has inspired me a lot. I would like also give my thanks to Robert Casper (BU drive) and Russ Schinzing (ERC Inc.) from remanufacturing industry for validating some of my modeling assumptions.

China Scholarship Council, Division of Production Economics in Linköping University, together with School of Economics and Management in Tongji University have supported me financially. It would be impossible for me to finish this research project without them.

My colleagues in the Division of Production Economics are very sincere, smart and light hearted. They are my good friends, who make me feel happy and comfortable to work in the group. I want to especially mention Kristina Karlsson for teaching me golf and interesting Swedish culture, and Jonas Ekblom for explaining me option theory.

I have been spent much of my spare time with all my Chinese friends in Sweden. They are like my closest families, who have helped me enjoy both the long dark winters and short bright summers here.

Finally, I want to thank my family for their unconditional love and support!

\author{
Linköping, December 2014
}





\section{List of Publications}

This dissertation entitled Core Acquisition Management in Remanufacturing - Current Status and Modeling Techniques is a summary of the author's studies in the doctoral research program in Division of Production Economics, Department of Management and Engineering at Linköping University. In this dissertation, the following six research papers are appended.

\section{Appended Papers}

\section{Paper 1}

Wei S. Tang O. Sundin E., 2014, Core (product) Acquisition Management for remanufacturing: a review, working paper, submitted to Journal of Remanufacturing.

\section{Paper 2}

Wei S., Cheng D., Sundin E., Tang O., 2014, Motives and barriers of the remanufacturing industry in China, submitted to Journal of Cleaner Production, under second round review.

An earlier version of the paper was presented on the $21^{\text {st }}$ EurOMA Conference, $20^{\text {th }}-25^{\text {th }}$, June, 2014, Palermo, Italy.

\section{Paper 3}

Wei S., Tang O., 2014, Managing cores for remanufacturing during the product life cycle, submitted to Annuals of Operations Research.

An earlier version of the paper was presented on the $17^{\text {th }}$ International Symposium on Inventory, $20^{\text {th }}-24^{\text {th }}$, August, 2012, Budapest, Hungary.

\section{Paper 4}

Wei S., Tang O., 2014, Real option approach to evaluate cores for remanufacturing in service markets, International Journal of Production Research, accepted, DOI:10.1080/00207543.2014.9 39243.

An earlier version of this paper was presented on the $11^{\text {th }}$ ISIR Summer School, $19^{\text {th }}-23^{\text {rd }}$, August, 2013, Neuchatel, Switzerland.

\section{Paper 5}

Wei S., Tang O., Liu W., 2014, Refund policies for cores with quality variation in OEM remanufacturing, International Journal of Production Economics, accepted, DOI:10.1016/j.ijpe.2014. 12.006

An earlier version of this paper was presented on the $18^{\text {th }}$ International Working Seminar on Production Economics, $24^{\text {th }}-28^{\text {th }}$, January, 2014, Innsbruck, Austria.

\section{Paper 6}

Wei S., Tang O., 2014, Refund polices for core collecting regarding the customers' responses, submitted to International Journal of Production Economics.

An earlier version of this paper was presented on the $18^{\text {th }}$ International Symposium on Inventory Research, 18 $8^{\text {th }}-22^{\text {nd }}$, August, 2014, Budapest, Hungary. 


\section{Other publications (not included in the dissertation)}

Wei S., Tang O., Wang D., 2011, A dynamic transshipment policy in a lost sales inventory system, Proceedings of the $21^{\text {st }}$ International Conference on Production Research, August, 2011, Stuttgart, Germany.

Musa S. N., Wei S., Tang O., 2011, Information flow and mitigation strategy in a supply chain under disruption, Proceedings of the $21^{\text {st }}$ International Conference on Production Research, August, 2011, Stuttgart, Germany. 


\section{Table of Contents}

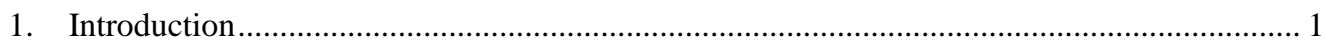

1.1 Core Acquisition Management ............................................................................... 2

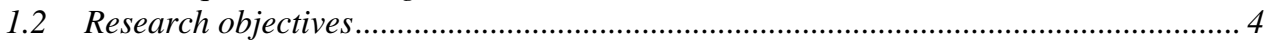

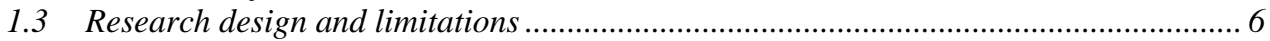

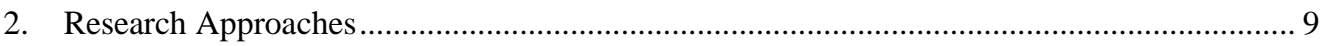

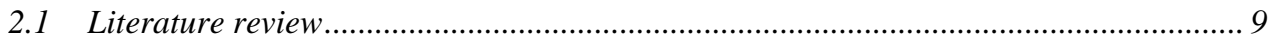

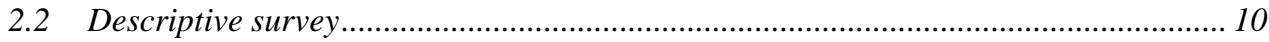

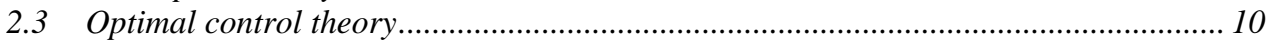

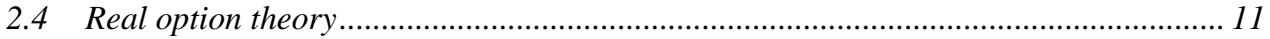

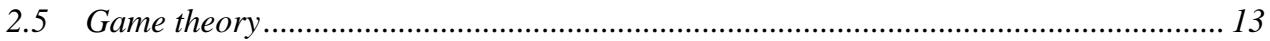

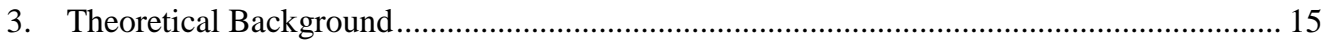

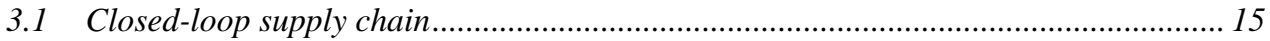

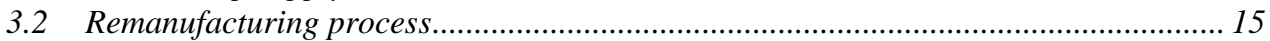

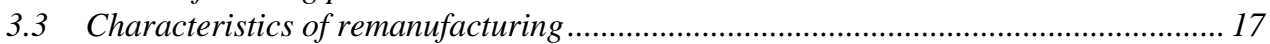

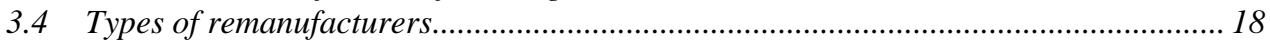

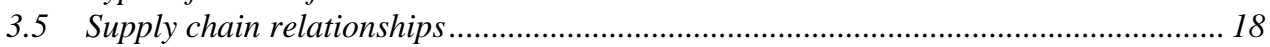

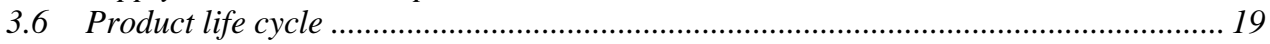

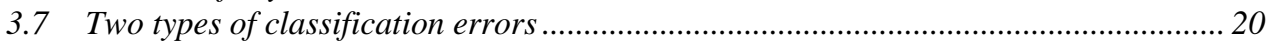

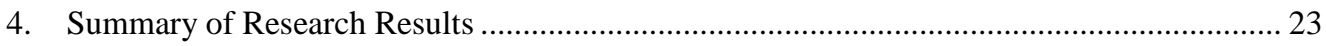

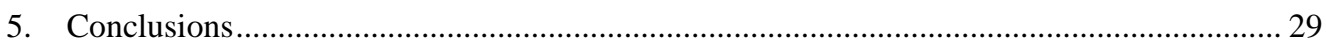

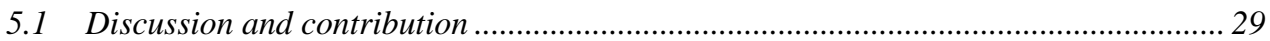

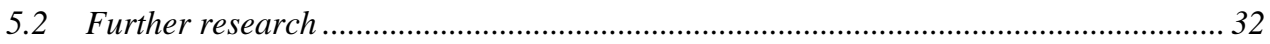

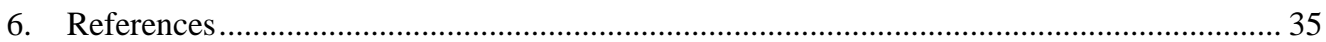

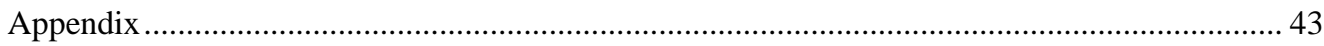

A. Questionnaire for "Motives and barriers of the remanufacturing industry in China"

B. The author's contributions to the appended papers

C. Appended papers 



\section{Introduction}

Our planet has been suffering from rapidly increasing of world's population and consumption of materials and energy. Technology updates are in such a quick pace that makes old products out of date even though they are still functioning well. The tension between economic development and environment protection has become especially serious in developing countries. For example, with its fast growing economy, China used 3013 MTOEs (Million Tonnes of Oil Equivalent) of energy in year 2013, about 1.5 times of the United States (Global Energy Statistical Yearbook 2014). On the other hand, according to Ministry of Environmental Protection (2014), none of its 74 major cities met the World Health Organization's recommendations for particulate matter of 2.5 micrometers or less (PM2.5), which is extremely harmful for health (Arden et al. 2002; Cesaroni et al. 2014). Water and soil pollutions have also been reported to be very serious in China (Pei 2014; Kaiman 2014). It has become increasingly critical to meet the desire for development more efficiently and wisely in a sustainable manner.

Remanufacturing, described as "the ultimate form of recycling" (Steinhilper 1998), is such a way to contribute to the sustainable development. In remanufacturing, the material and energy in the products are partly conserved to be used again, thus forming the closed loop. Cummins remanufacturing reclaimed 50 million pounds of product in 2012 and avoided 200 million pounds of greenhouse gas. It also reports that remanufacturing requires them about $85 \%$ less energy than manufacturing a brand new product (Cummins Inc. 2014). LMI Inc. reports that $95 \%$ of energy used to make OEM cartridges is saved by remanufacturing (LMI Inc. 2014). CARDONE remanufactured 68,255 tons of discarded or non-usable auto parts in 2012. Besides, in the remanufacturing process, 5,833 tons of cardboard, 14,815 gallons of waste oils and 30 tons of electronic boards, PC monitors and telecommunications equipment were also recycled (CARDONE industries 2014).

There exist many definitions of remanufacturing. While a more general combination of the various definitions is provided by Sundin (2004): Remanufacturing is an industrial process whereby used products (referred as cores) are restored to useful life. During this process the core passes through a number of remanufacturing steps, e.g. inspection, disassembly, part replacement/refurbishment, cleaning, reassembly, and testing to ensure it meets the desired products standards. There are also narrower definitions that require the quality standards of remanufactured products reach the same or like new condition (Lund 1984). In this dissertation, the general one is mostly used for providing an overall understanding of remanufacturing. Remanufacturing has many synonymous, such as rebuilding, refurbishing, reconditioning, overhauling, etc. Increasingly, remanufacturing is becoming a standard and generic term (Lund 1996; Steinhilper 1998).

The remanufacturing industry had its boost since World War II, when manufacturing was performed due to resource (labor, material, etc.) scarcity. Since then remanufacturing has been carried out in various product categories, such as car parts, heavy duty machineries, photo copiers, toner cartridges, military equipment, office furniture, etc. (Sundin 2004). In UK, the value of remanufacturing is estimated at 2.3 billion GBP in 2009 with 50,000 employees (Chapman et al. 2009). While in the United States, remanufacturing has become a major business, and there are over 70,000 remanufacturing companies, with total sales of 53 billion USD (Lund 1996). 
Nevertheless, remanufacturers often face many challenges in practice, among which Core Acquisition Management is essential for the success of the remanufacturing business.

\subsection{Core Acquisition Management}

Cores are the used products/parts that are collected to be further processed in remanufacturing operations. They are the essential resources for remanufacturing, as stated by Electronic Remanufacturing Company (ERC), "who owns the core owns the market" (Schinzing 2010), and Caterpillar, "cores are the backbones of the Caterpillar remanufacturing" (Caterpillar Inc. 2014).

Core Acquisition Management is the active management of the quality, quantity and timing of collected cores. It not only determines the profitability of the remanufacturing business for a company, but also affects various operational issues, such as facility design, production planning and control policies, and inventory policies (Guide and Van Wassenhove 2001). Guide and Jayaraman (2000) firstly formally brought up the concept of Production Acquisition Management as an interface between reverse logistics activities and production planning and control activities for firms engaged in value-added recovery. The primary function of the product acquisition management is described by Guide and Jayaraman (2000) to reduce the uncertainty of return process, and to improve the balance between return and demand (Figure 1). Since this dissertation is set specifically in a remanufacturing background, the term "Core Acquisition Management" is used instead, to indicate its remanufacturing focus. As explained in Figure 1, the cores returned from market are usually with higher uncertainties in terms of volume, timing and quantity. Core Acquisition Management manages these uncertainties, in order to make the manufacturing/remanufacturing operations more efficient, and finally supplies the market with products that are better matched with the demand.

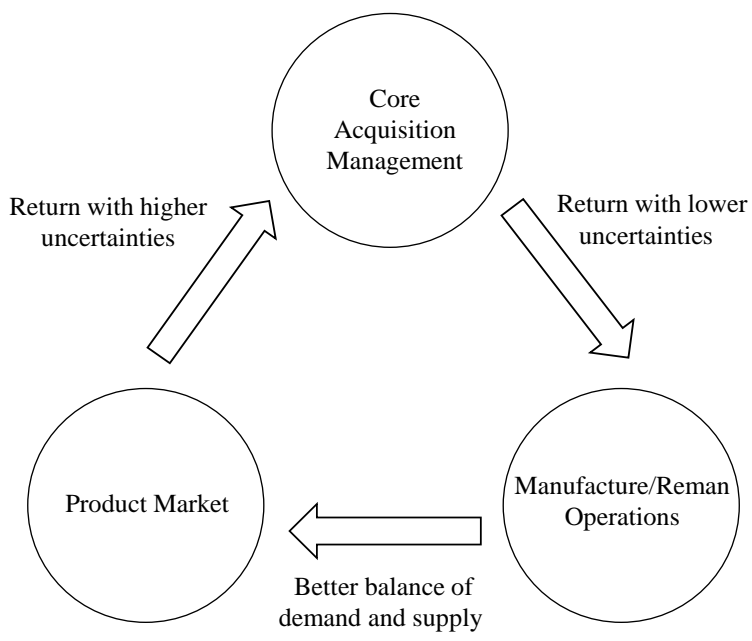

Figure 1. Core Acquisition Management in a closed-loop supply chain (adapted and developed based on Guide and Van Wassenhove 2001)

The uncertainties of the returns mainly include two aspects: the uncertainties of return volume and timing, and the uncertainty of core quality. They are of the major challenges in remanufacturing business (Guide et al. 2000). 


\section{Uncertainty of return volume and timing}

The uncertainty in return volume and timing can be caused by many factors: the life-cycle stage of a product, the rate of technological change, the supply chain relationship, etc. This uncertainty is one of the major characteristics for remanufacturing (Guide et al. 2000). It results in further difficulties in forecasting of returned cores and core availability, production and resource planning, and inventory control. Due to the uncertainties in return volume and timing, core inventories account for one third of the inventory carried in a typical remanufacturing process (Nasr et al. 1998). However, as reported in the survey conducted by Guide and Jayaraman (2000), over half $(61.5 \%)$ of the firms have no control over the timing and quantity of returns. Firms reporting some methods of control mainly use a core deposit system or a variation of it.

\section{Uncertainty of core quality}

Due to different environmental conditions, time lengths and intensities of how the products are used, the returned cores are usually quite different in quality conditions. In addition, the exact quality conditions cannot be precisely observed, until the core has been fully disassembled, cleaned and tested. The uncertainty of core quality leads to a high variation of material recovery rates (a measure of how often parts are remanufacturable, see Guide and Srivastava 1997) and processing times of remanufacturing, which in turn results in highly varied remanufacturing costs. The survey of Guide and Jayaraman (2000) reports that the average material recovery rate from cores is $63.8 \%$, but the recovery rates for individual part range from a low level of $19.1 \%$ to a high level of $81.9 \%$. Denizel et al. (2010) describe an example of two end-of-lease laptops that are returned in IBM's remanufacturing facility in Raleigh N.C. While one needs only 15 minutes production capacity to perform testing, cleaning, formatting of the hard drive, and software configuration, the other needs 45 minutes of production capacity to also change broken latch, keyboard and a non-standard memory configuration. In this case, the returned cores again exhibit different qualities.

In order to balance the market demand and core supply, as well as achieve a lower operational cost, Core Acquisition Management needs to deal with the above two major aspects. One aspect concerns the uncertainty of return volume and timing, i.e., how many cores should be acquired and at what time? The remanufacturer can apply control by adjusting its collecting effort in the forms of deposit, credit, buy-back price, among others. Such approaches are suggested by Electronics Remanufacturing Company (Schinzing 2010), where deposit should be adjusted to acquire as many cores as possible in the early life-cycle, and keep core collecting rate equal sales later. Then by the time selling becomes zero, core collecting rate should also be reduced to zero. The other aspect relates with the uncertainty of return quality, i.e., what kind of cores should be acquired. To control the quality of returned cores, inspections and quality classifications can be performed according to predetermined quality standards. For example, in ReCellular Inc. the collected mobile telephones are categorized in six different nominal quality classes and acquired at different prices (Guide and Van Wassenhove 2001). Based on the problems described above, the research objectives of this dissertation are formulated in the next section. 


\subsection{Research objectives}

The aim of this dissertation is to extend the knowledge about Core Acquisition Management in remanufacturing, by investigating the current status of research and industrial practice, and developing quantitative models that assist decision making in the core acquisition process in remanufacturing. The research in this dissertation is proceeded in two steps, firstly to identify the research gaps and industrial needs (research objective 1), which serve as the guideline for supporting the detailed analysis of specific research issues. Furthermore, the methods to deal with the main difficulties in Core Acquisition Management: uncertainties of return volume and timing, the uncertainty of core quality, are investigated respectively in research objectives 2 and 3. These research objectives are described in more details as follow, and their relationships are illustrated in Figure 2.

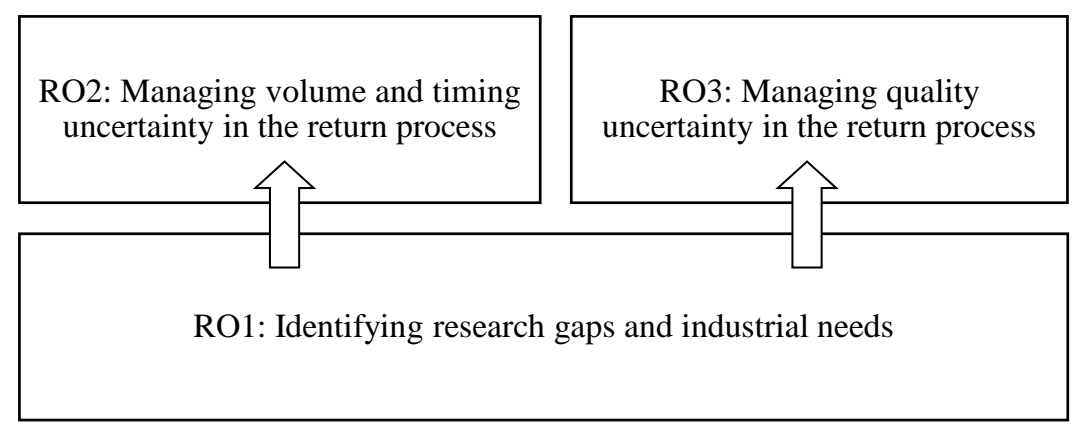

Figure 2. The relationship of the research objectives

Research objective 1: Identifying research gaps and industrial needs in Core Acquisition Management

Understanding research gaps is a requirement of most operations management reserach. In order to decide the optimal acquisition policies, quantitative modeling approaches are widely used in the studies of Core Acquisition Management area. There have been literature review focusing on different aspects in remanufacturing, such as, closed-loop supply chain (Souza 2013), production planning and control (Guide 2000; Lage and Godinho 2012), reverse logistics (Fleischmann et al. 1997; Rubio et al. 2008), disassembly (Kim et al. 2007), design for remanufacture (Hatcher et al. 2011). In some of these studies, Core Acquisition Management is sometimes investigated as a sub topic. However, no review specifically addresses this topic as the main focus, therefore an analysis of this area is still necessary due to its importance.

In terms of industrial needs, even though there have been previous investigations, such as survey studies conducted in Guide and Jayaraman (2000) and case studies in Seitz (2007) and Östlin et al. (2008). Such empirical studies are still relatively limited in a quick changing remanufacturing industry, especially in some fast developing countries, such as China, despite their growing potential and special market environment. Therefore, a survey in Chinese remanufacturers about their general motives and barriers is able to contribute the existing knowledge about the industrial needs in remanufacturing. 
The following studies are conducted to fulfill this objective:

- Core (product) Acquisition Management for remanufacturing: a review

- Motives and barriers of the remanufacturing industry in China

Research objective 2: Developing models for core acquisition decisions to manage return volume and timing uncertainties

This research objective has a focus on the core acquisition decisions providing the dynamic unbalance between return and demand. From a strategic point of view, the dynamic unbalance between return and demand is caused by the product life cycle and the time lag of returned cores: when the demand of the products is relatively high in the beginning of the product life cycle, the returns are not enough because most of customer are still using the products; while later this relation changes, as the returned volume increases because more end-of-life products and the demand enter into a stable or decline phase (Steinhilpher 1998; Guide et al. 2000; Schinzing 2010).

From the operational perspective, the decision on accepting or rejecting a core depends on the remanufacturer's evaluation of the core. However, to evaluate the core properly with the high uncertainty of demand and return in the future is difficult. In addition, when facing these uncertainties, the remanufacturer also has the option to dispose a core when the actual demand turns out to be low or alternatively when remanufacturing the core is not economically justified. Thus a core evaluation method should be developed to capture the uncertainties as well as the managerial flexibility.

The following studies are conducted to fulfill this objective:

- Managing cores for remanufacturing during the product life cycle

- Real option approach to evaluate cores for remanufacturing in service markets

Research objective 3: Developing models for core acquisition methods to manage the uncertainty of core quality

The focus of this research objective is to investigate the methods to better deal with the quality uncertainty of the cores. This research objective is mainly studied in the dissertation within a deposit-refund core collection system, which is commonly used to control the core acquisition process (Guide and Jayaraman 2000). In a deposit-refund collection system, the remanufacturer charges the customers a certain amount of deposit when selling the products, and refunds the deposit fully or partly back according to the cores that are returned by the customer later. In order to manage the quality variation of cores, quality inspection and classification are usually used either at the collection sites or at the remanufacturing site before disassembly. A more accurate inspection and classification mechanism is able to lower the core inventory level thus it reduces acquisition and disposing costs. It also results in shorter queues, better machine and labor utilization and more predictable flow times (Guide and Van Wassenhove 2001). However, it requires additional inspection and administration costs. The customers' purchase and return behavior must also be taken into consideration when designing such quality managing policies.

The following studies are conducted for this objective:

○ Refund policies for cores with quality variation in OEM remanufacturing 
- Refund polices and core classification errors in the presence of customers' choice behavior in remanufacturing

\subsection{Research design and limitations}

The included papers in this dissertation are listed in Table 1. They are designed with the aim to address the research objectives that are proposed in Section 1.2. Their relations are briefly introduced as follows.

Paper 1 and Paper 2 provide the motivations and background of the dissertation from the perspectives of academy and industry, respectively. Paper 1 investigates current research status focusing on Core Acquisition Management problems, and it also aims to find the research gap. Based on a (descriptive) survey conducted in China, Paper 2 attempts to understand the motives and barriers of Chinese remanufacturing industry, which is a fast growing industry with huge potential of development. Even though from different perspectives, both Paper 1 and Paper 2 identify the research needs of Core Acquisition Management.

Table 1. The relations between research objectives, studies and main research methods

\begin{tabular}{|c|c|c|}
\hline Research Objectives & Studies & $\begin{array}{l}\text { Main research } \\
\text { methods }\end{array}$ \\
\hline \multirow{2}{*}{$\begin{array}{l}\text { RO1: Identifying research } \\
\text { gaps and industrial needs in } \\
\text { Core Acquisition Management }\end{array}$} & $\begin{array}{l}\text { Core (product) Acquisition Management for } \\
\text { remanufacturing: a review (Paper 1) }\end{array}$ & $\begin{array}{l}\text { Literature } \\
\text { review }\end{array}$ \\
\hline & $\begin{array}{l}\text { Motives and barriers of the remanufacturing } \\
\text { industry in China (Paper 2) }\end{array}$ & $\begin{array}{l}\text { Descriptive } \\
\text { survey }\end{array}$ \\
\hline \multirow{2}{*}{$\begin{array}{l}\text { RO2: Developing models for } \\
\text { core acquisition decisions to } \\
\text { manage return volume and } \\
\text { timing uncertainties }\end{array}$} & $\begin{array}{l}\text { Managing Cores for Remanufacturing during the } \\
\text { Product Life Cycle (Paper 3) }\end{array}$ & $\begin{array}{l}\text { Optimal con- } \\
\text { trol theory }\end{array}$ \\
\hline & $\begin{array}{l}\text { Real option approach to evaluate cores for re- } \\
\text { manufacturing in service markets (Paper 4) }\end{array}$ & $\begin{array}{l}\text { Real option } \\
\text { valuation } \\
\text { theory }\end{array}$ \\
\hline \multirow{2}{*}{$\begin{array}{l}\text { RO3: Developing models for } \\
\text { core acquisition methods to } \\
\text { manage the uncertainty of core } \\
\text { quality }\end{array}$} & $\begin{array}{l}\text { Refund policies for cores with quality variation } \\
\text { in OEM remanufacturing (Paper 5) }\end{array}$ & $\begin{array}{l}\text { Nonlinear } \\
\text { optimization }\end{array}$ \\
\hline & $\begin{array}{l}\text { Refund polices for core collecting regarding the } \\
\text { customers' responses (Paper 6) }\end{array}$ & Game theory \\
\hline
\end{tabular}

Based on the motivations from Paper 1 and Paper 2, different analytical modeling methods are applied in Papers 3, 4, 5 and 6 for specific problems in Core Acquisition Management (Table 1).

Paper 3 is designed to use optimal control theory to deal with a long-term strategic issue, which is to decide how many cores to collect and remanufacture during different stages of the product life cycle. During such a product life cycle, both the demand for remanufactured products and the core availability change to formulate a dynamic relationship. Besides such a relationship, the remanufacturing cost may decrease with the core inventory because of the availability of high quality cores and economics of scale. The price of a core may also change along with time due to 
varied conditions of supply. All these dynamic relations make the core acquisition a complicated issue.

Paper 4 applies real option valuation approaches for evaluating cores and making core acquisition decisions in an uncertain remanufacturing environment. Compared with the traditional valuation approaches such as NPV (net present value) method, this approach better captures the value of flexibility in owning cores and when predicting the return and demand is difficult. It also brings in advantages in dealing with the correlation of stochastic demand and return. Such correlation exists by the fact that the customers also play the role as core suppliers, or due to the acquisition competitions between different collectors so that less cores will be available when demand is high. It is an important issue but relatively less considered in the literature.

Both Paper 5 and Paper 6 focus on the detailed settings of specific core acquisition mechanisms i.e., a deposit-refund policy, which is common for controlling the core acquisition process. Paper 5 focuses more on optimizing the settings of the deposit and quality partition, with the consideration of quality variation, whereas Paper 6 uses game theory to study the influences of the quality classification errors during the interaction between the customers and remanufacturers.

This dissertation studies only several limited issues in Core Acquisition Management, more specifically, the motives and barriers of remanufacturers, core valuation and acquisition planning, quality classification and inspection problems. Certainly there are many other activities in Core Acquisition Management that are worth to be investigated, for examples, return forecast, reverse logistics network, reverse channel design, etc. Even with the focused topics in Papers 3-6, the problems and analysis are based on certain settings and assumptions. In other words, a framework of solution for Core Acquisition Management is not provided, neither it is the intention of this dissertation. Secondly, each research method does have its advantages and limitations. The limitations of used research method are explained with more details in the next section. 



\section{Research Approaches}

This dissertation applies Operations Management research methods to extend the knowledge and provide practical managerial insights in Core Acquisition Management area. In order to deal with different aspects of core acquisition problems as mentioned in previous section, various research approaches in Operations Management, such as literature review, descriptive survey, optimal control, real option valuation and game theory are used in this dissertation. In this section, these research methods, as well as the reasons for using them are briefly introduced. Some basic optimization methods, such as nonlinear optimizing and dynamic programming, are used in this dissertation but are not included in this section.

\subsection{Literature review}

A literature review is an account of what has been published on a topic by accredited scholars and researchers. Generally, the purpose of a review is to analyze critically a segment of a published body of knowledge through summary, classification, and comparison of prior research studies, reviews of literature, and theoretical articles (The University of Wisconsin-Madison Writing Center 2009). Conducting literature reviews is important in order to understand what has been done and what needs to be done. A literature review may constitute an essential chapter of a thesis or dissertation, or may be a self-contained review of writings on a subject. A literature review must be able to address the following issues (Taylor 2014):

- Be organized around and related directly to the thesis or research questions you are developing;

- Synthesize results into a summary of what is and is not known;

- Identify areas of controversy in the literature;

- Formulate questions that need further research.

The development of the literature review requires the following four stages (University of California Santa Cruz 2014):

- Problem formulation - which topic or field is being examined and what are its component issues?

- Literature search-finding materials relevant to the subject being explored;

- Data evaluation - determining which literature makes a significant contribution to the understanding of the topic;

- Analysis and interpretation - discussing the findings and conclusions of pertinent literature.

Literature reviews have been conducted in many topics in remanufacturing related research, such as, in production planning and control (Guide 2000; Lage and Godinho 2012), reverse logistics (Fleischmann et al. 1997; Rubio et al. 2008), disassembly (Kim et al. 2007), design for remanufacture (Hatcher et al. 2011), etc. As discussed before, successful Core Acquisition Management is critical for the remanufacturers, and recently the researchers have paid more attention to this area (Bulmus et al. 2014). This specific topic in remanufacturing area deserves its own attention, therefore a literature review is conducted with the aim to describe the research status, identify the research gaps and consequently propose possible further research directions. 


\subsection{Descriptive survey}

Survey is a research method that collecting information from a subset of elements that belong to the entire group of people, firms, plants or things that the researcher aims to investigate. The sample is selected according to certain rules so that the research can obtain information about a large population with a certain level of accuracy (Rea and Parker 1992). Survey research requires a pre-existing theoretical model (or conceptual framework), and a number of related sub-process: the process of translating the theoretical domain into the empirical domain, the design and pilot testing processes; the process of collecting data for theory testing; the data analysis process; and the process of interpreting the results and writing report (Karlsson 2009).

Survey can be distinguished between explorative, confirmatory (theory testing), and descriptive survey research (Pinsonneault and Kraemer 1993; Filippini 1997; Malhotra and Grover 1998), according to their ways to contribute to scientific knowledge. Descriptive survey research aims at understanding the relevance of a phenomenon and describing the incidence or distribution of the phenomenon in a population. The primary research objective is not theory development, although through the facts described it can provide useful hints both for theory building and theory refinement (Karlsson 2009). In other words, it does not answer questions about how/when/why the characteristics occurred, rather it addresses "what" are the characteristics of the studied population or situation (Shields and Rangarjan 2013).

For understanding better the motives and barriers of the remanufacturers in practice, descriptive survey is able to help the researcher to identify and validate their research focuses, aid the practitioners to improve their business, and also assist the policy makers to establish or adjust proper regulations and policies to encourage the industry's development. Such a method has been used in previous studies to understand the status of remanufacturing industry, such as the survey of Lund (1984) in the United States, Sundin et al. (2005) and Lundmark et al. (2009) in Sweden, Guidat et al. (2014) in Finland, among others.

\subsection{Optimal control theory}

Optimal control theory is a branch of mathematics developed to find optimal solutions to control a dynamic system that evolves over time (Sethi and Thompson 2000). A typical dynamic system has various states, which can be expressed as the state variable $x(t)$ at time $t \in[0, T]$. The state can be controlled through changing the control variable $u(t)$, where $u(t)$ is constrained by $u(t) \in \Omega(t)$. The change of state caused by control variable at time $t$ is expressed by the differential equation:

$$
x^{\prime}(t)=f(x(t), u(t), t), x(0)=x_{0},
$$

where $x^{\prime}(t)$ is the first order derivative of $x(t)$ with respect to time $t$. With the control trajectory $u(t)$ over $[0, T]$ and the initial state $x(0)$, the state trajectory $x(t)$ over time $[0, T]$ can then be derived. The aim is to choose proper control $u(t)$ to maximize the following objective function:

$$
J=\int_{0}^{T} F(x(t), u(t), t) d t+S[x(T), T],
$$

with the constraint $u(t) \in \Omega(t), t \in[0, T]$. In the objective function, $F$ is a function that measures the system benefit, and $S$ is the salvage value of the ending state $x(T)$ at time $T$. 
Sometimes the above constraint is specified as mixed inequality constraints

$$
g(x(t), u(t), t) \geq 0, t \in[0, T]
$$

or pure state inequality constraints

$$
h(x, t) \geq 0, t \in[0, T] .
$$

Also the terminal state $x(T)$ could be limited in a set as

$$
x(T) \in X(T) .
$$

Optimal control theory originates from the calculus of variations. Swiss mathematician Leonhard Euler and Italian mathematician Joseph-Louis Lagrange are generally considered as the founders of the calculus of variations. The starting of the modern control theory was indicated by the publication in Russian in 1958 (English version in 1958) of the book: The Mathematical Theory of Optimal Process, by Pontryagin, Boltyanskii, Gamkrelidze and Mishenko (1962). In this book, the maximum principle for optimal control problem is proved. By using the maximum principle, the dynamic problem can be decoupled into a series of problems that holds at each instant of time. The optimal solutions to these instaneous problems can be shown to give the optimal solutions to the overall problem.

Optimal control theory has been used in economics research areas, such as finance, production and inventory, marketing, maintenance and replacement, and consumption of natural resources (Sethi and Thompson 2000). Besides its applications in economics research area, optimal control theory is also widely used in other fields such as aerospace, process control, robotics, bioengineering, etc. (Becerra 2008).

The remanufacturing production system is a dynamic control system. Inventory levels of cores or remanufactured products can be viewed as its state, which is controlled by the core acquisition effort and volume, and remanufacturing production plan. The inventory level in turn affects the remanufacturer's ability and efficiency in conducting remanufacturing activities and serving its demand. The demand and core supply are usually constantly changing along with time because of the uncertainties and the product life cycle issues. Such dynamic relations between demand and core supply add constraints on the decisions of remanufacturer's core acquisition and remanufacturing production.

As described earlier, for such a dynamic control system, the optimal control theory provides an alternative to derive the solutions of acquisition volume or effort, in order to optimize the system's performances by maximizing profit or minimizing its cost. Such attempts have been made in previous studies in remanufacturing, for instances, Minner and Kiesmüller (2012), Kiesmüller (2003) and Minner and Kleber (2001).

\subsection{Real option theory}

Real option valuation (ROV) applies option valuation techniques in finance for capital budgeting decisions (Borison 2005). A financial call option on an asset gives the right, with no obligation, to acquire the underlying asset at a pre-specified price (the strike price) on or before a given maturity; similarly a put option gives the right, but not the obligation, to sell the underlying asset and receive the exercise price (Hull 2005). The value of the option comes from the flexibility to 
choose whether to exercise such an option, depending on the change of asset's value. The basic option valuation techniques in finance include the Black-Scholes-Merton model (Black and Scholes 1973), binomial lattices method, Monte Carlo simulation.

The value of a real option originates from the managerial operating flexibility to deal with the market/environment uncertainty. These flexibilities could include the option to defer, time-tobuild option, the option to alter, the option to abandon, the option to switch, growth options, multiple interacting options, and others (Trigeorgis 2000). The above mentioned option valuation techniques in finance can be further extended and applied to analyze different types of real options.

Compared with real option valuation method, traditional valuation methods, such as discountedcash-flow (DCF), make implicit assumptions that an "expected scenario" of cash flows and presume management's passive commitment to a certain static operating strategy. Due to the managerial flexibility of adapting future actions depending on the future environment, an asymmetry or skewness in the probability distribution of NPV is introduced. The probability of the upside potential NPV is improved, while the downside losses relative to management's initial expectations under passive (static) management can be reduced (Figure 3). This results in an "option premium", which can be expressed as: $E\left(N P V_{\text {expanded }}\right)=E\left(N P V_{\text {static }}\right)+$ option premium. The motivation for using option valuation approaches arises from its potential to conceptualize and quantify such "option premium" (Trigeorgis 2000).

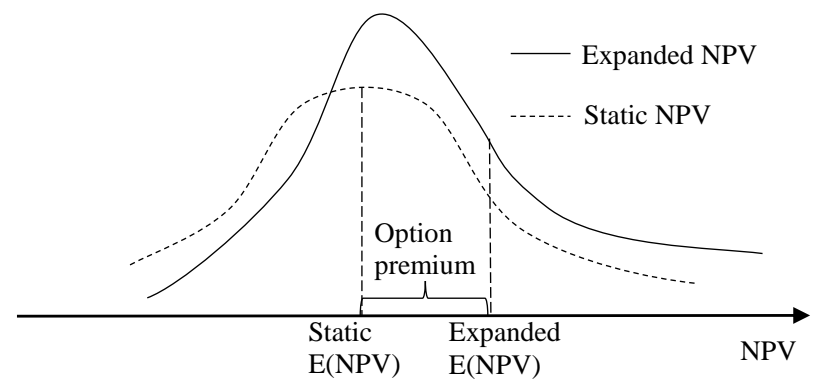

Figure 3. The value of managerial flexibility (adapted from Trigeorgies 2000)

ROV is used commonly in energy sector (Fernandes et al. 2011 and Ceseña et al. 2013), where data availability is less a problem. ROV has also been used to evaluate the flexibility in manufacturing systems (Bengtsson 2001; Bengtsson and Olhager 2002a; Bengtsson and Olhager 2002b; Berling 2008). Other applications include the valuation of R\&D projects, real estate development, competition and corporate strategies, among others. Reviews of the applications of ROV methods can be found in Lander and Pinches (1998) and Trigeorgis (2000).

Despite the similarities between financial options and real options, there are also important differences that need special attentions when applying ROV principles (Kester 1993; Trigeorgis 2000). For example, different with financial assets, some real assets are not easily to be traded. These non-traded real assets may earn a return which is below the equilibrium rate of return as in the financial market with comparable traded financial securities of equivalent risk. In such a case, 
it requires a dividend-like adjustment in a valuation of real options (McDonald and Siegel 1984, 1985).

To deal with the uncertainty of remanufactured product price, Liang et al. (2009) assume that the market price follows the Geometric Browning Motion and the remanufacturer can sell the product at a specified forecasted price at the expiration time. The Black-Scholes-Merton model is then applied to determine the value of the core. However in practice, it is more common that the remanufactured products will be sold at the market price, and the remanufacturer can determine to dispose the core for salvage value earlier.

The uncertainty of remanufacturing cost due to varying core quality is considered in Shi and Min (2013). Facing such an uncertainty, the remanufacturer has the option to remanufacture or dispose a core depending on the observed cost. The cost thresholds for remanufacturing should be derived to define the conditions under which the remanufacturing option should be exercised. In addition, the influence of government policies, i.e. subsidy and disposal fee, and environmental performances are also examined.

\subsection{Game theory}

Game theory is the "study of mathematical models of conflict and cooperation between intelligent rational decision-makers" (Myerson 1991). Modern game theory began with the idea regarding the existence of mixed-strategy equilibria in two-person zero-sum game, with the proof by John Von Neumann (Neumann 1928). Along with the later development, Game theory has been widely applied in economics, political science, psychology, computer science, and biology, among other disciplines. The games in game theory must specify the following elements: the players of the game, the information and actions available to each player at each decision point, and the payoffs for each outcome (see Rasmusen 2007).

Player $i$ 's strategy $s_{i}$ is a rule that tells him which action to choose at each instant of the game, given his information set. Player $i$ 's strategy set or strategy space $S=\left\{s_{i}\right\}$ is the set of strategies available to him. A strategy combination $s=\left(s_{1}, \ldots s_{n}\right)$ is an ordered set consisting of one strategy for each of the $n$ palyers in the game.An equilibrium $s^{*}=\left(s_{1}^{*}, \ldots, s_{n}^{*}\right)$ is a strategy combination consisting of a best strategy for each of the $n$ players in the game.

An equilibrium concept or solution concept is a rule that defines an equilibrium based on the possible strategy combinations and the payoff functions. Two of the best known equilibrium concepts are dominant strategies and Nash equilibrium (Nash 1950). A strategy is a dominant strategy, if it is a player's strictly best response to any strategy that the other players might pick. While dominant strategy equilibrium is a strategy combination consisting of each player's dominate strategy, Nash equilibriums is a strategy combination, where no player has incentive to deviate from this strategy given that the other players do not deviate (Rasmusen 2007).

Games can be divided into the following categories using different criteria, such as cooperative and non-cooperative, symmetric and asymmetric, zero-sum and non-zero-sum, simultaneous and sequential, perfect information and imperfect information, etc. (Rasmusen 2007).

Game theory has been used widely in supply chain management to coordinate different agents, who often have conflicting objectives (Cachon and Netessine 2004). In remanufacturing research area, game theory is used to analyze the competition between OEM and independent remanufac- 
turers who compete on collecting cores and demand, for examples, Örsdemir et al. (2014) and Bulmus et al. (2014), collection channel design with the consideration of whether the cores should be collected by retailer, third party collectors, or OEMs, such as Savaskan et al. (2004), Savaskan and Van Wassenhove (2006). Concerning the core acquisition problem, the customers (or other core supplier) and the remanufacturers could have conflicted objectives. The remanufacturers set the acquisition policy to collect cores for further remanufacturing, while the customers can either return the cores to the remanufacturers for possible credit or refund, or sell them to other core collectors. Their decision making should take into account each other's possible responses. Therefore, game theory can be used here to understand the acquisition policy and its influences on the choice behavior of the decision makers.

The criticism of using game theory is usually concerned with the players' knowledge of the payoffs and their rationality. For examples, sometimes it is even difficult to determine an appropriate payoff function for a single player. The theoretical randomized strategies could also be a problem when a game is played once or only a few times, when the players are very likely to experience regret, which is eliminated by using expected-case analysis (LaValle 2006). 


\section{Theoretical Background}

In this chapter, in order to provide the background knowledge for the readers to understand the specific industry environment and settings in this dissertation, the key theory terms are introduced. They are closed-loop supply chain, remanufacturing process, characteristics of remanufacturing, types of remanufacturers, supply chain relationships, product life cycle and two types of classification errors.

\subsection{Closed-loop supply chain}

The flow of material in a forward supply chain is unidirectional, from suppliers to manufacturers, distributors, retailers, and finally towards consumers. In a Closed-Loop Supply Chain (CLSC), there are also reverse flows of material sending back to the supply chain (Souza 2013). The reverse flows can re-enter the supply chain at different stages and consequently exhibit different recovery options, such as reuse, repair, refurbishing, remanufacturing, cannibalization and recycling (Thierry et al. 1995). In a closed-loop supply chain, Core Acquisition Management could appear in various product recovery stages as shown in Figure 4.

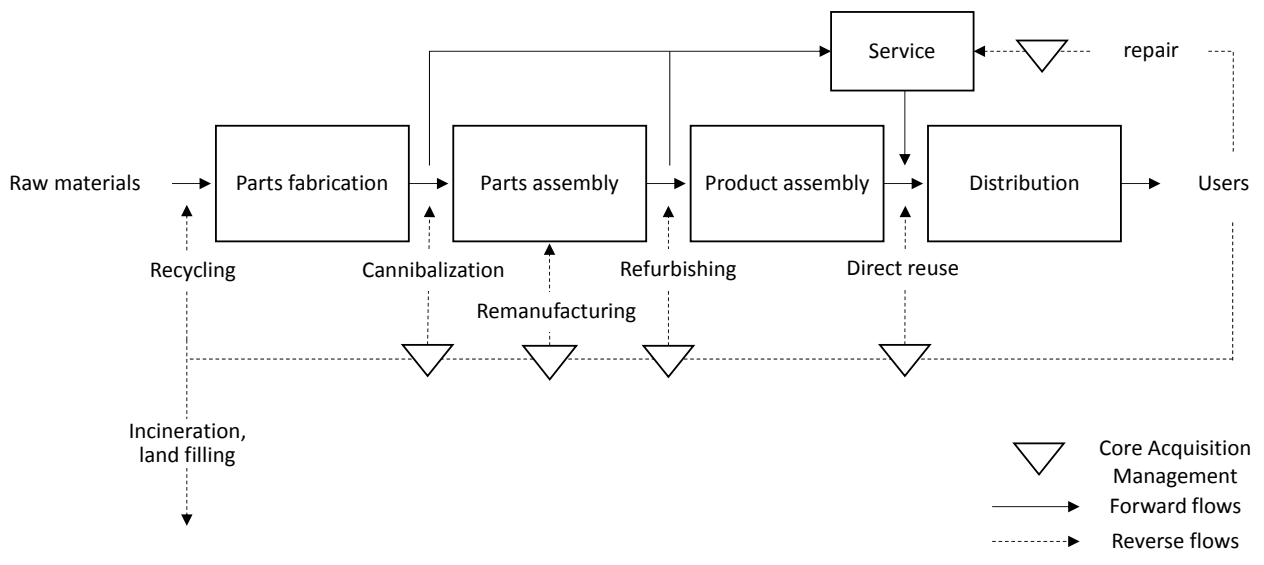

Figure 4. Core Acquisition Management in a closed-loop supply chain (adapted and developed based on Thierry et al. 1995)

Closed-loop supply chain management may be defined as: the design, control, and operation of a system to maximize value creation over the entire life of a product with the dynamic recovery of value from different types and volumes of returns over time (Guide and Van Wassenhove 2009). Remanufacturing is different with other recovery options in that it highly recaptures value (Lund 1984). The CLSC research has evolved from technical focus on remanufacturing large capital goods such as locomotive engines and airframes, to a subarea of supply chain management (Guide and Van Wassenhove 2009). Reviews in this area can be found in Atasu et al. (2008), Guide and Van Wassenhove (2009) and Souza (2013).

\subsection{Remanufacturing process}

The process within which the used product is remanufactured is called the remanufacturing process (Östlin 2008). The possible operations in a general remanufacturing process are included in 
Figure 5, where no particular order is specified. Actually, such order is dependent on situations, such as core volumes and core dirtiness. Also note that not all operations listed below have to be included in a remanufacturing process.

Notice that Core Acquisition Management controls and manages the input, i.e. the cores that enter into remanufacturing process, in order to achieve a better balance of the return and demand, and lower the remanufacturing complexity and cost.

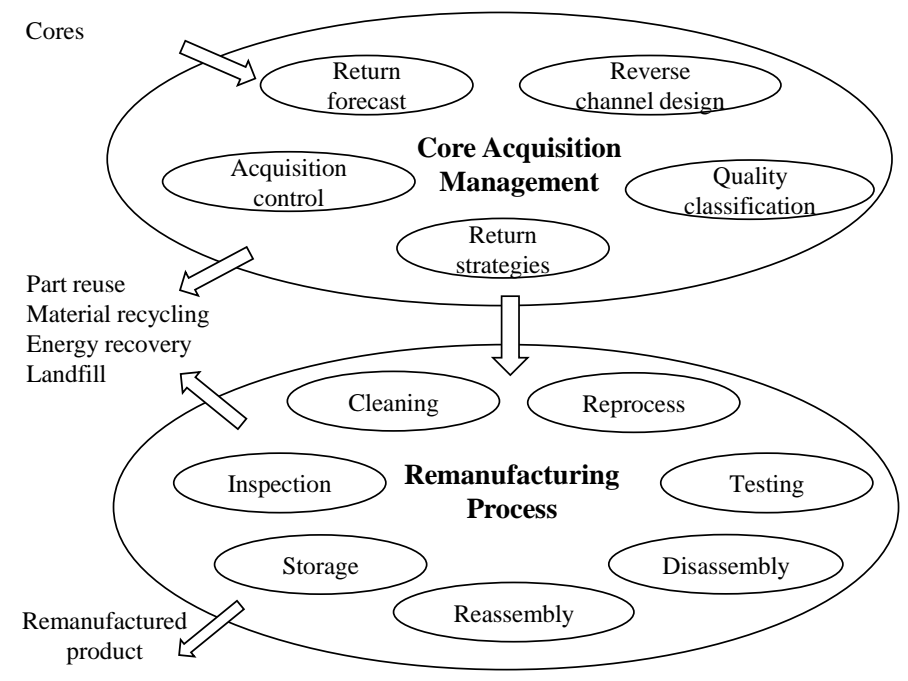

Figure 5. A general remanufacturing operation process (adapted and extended from Sundin 2004)

In Core Acquisition Management, based on the information from return forecast, the remanufacturer strategically designs its reverse channel, and decides which kinds of return strategies that will be used for core collection. On a tactical/operational level, the remanufacturer plans the acquisition volume and related acquisition effort (acquisition control) for each quality class of cores.

In disassembly, the product is disassembled to a component level. These components are firstly identified and inspected, and decision is made whether they can be reused in their current state or if they should be scrapped or recycled. Disassembly can be a quite complicated process involving scheduling issues (Kim et al. 2007). Inspection is performed to decide the component's quality, and if and how the component should be reprocessed. The cleaning operation can be very time consuming and complex (Steinhilper 1998), which may include dirt removing, degreasing, de-oiling, de-rusting, and freeing components from paint. Methods developed for cleaning include sand blasting, steel brushing, baking ovens, cleaning petrol, chemical and hot water baths, etc. Reprocessing is to repair and increase the quality of the core, where change of the components' geometrical dimensions may be necessary through metal cutting like grinding. Reassembly can be done with components that are either reused, reprocessed, taken from previous cores or even new components. The reassembly is often done using power tools and assembly equipment as in new product assembly (Östlin 2008). Final testing of the product is executed 
to ensure the products' performance. During the whole process, the components' quality is continuously assured through applied measurements (Steinhilper 1998).

The sequence and processing time of the above procedures are not only dependent on specific requirement in production, but also can be greatly influenced by the quality and quantity of the incoming cores. Therefore in this dissertation, we focus mainly on the starting of the above remanufacturing process: to manage the incoming cores in terms of acquisition volume and quality.

\subsection{Characteristics of remanufacturing}

Compared to traditional manufacturing, remanufacturing has its own characteristics, which require different operation techniques. In the study of Guide et al. (2000), seven characteristics of remanufacturing operations are summarized, and they are widely referred to by later research in remanufacturing area (for examples, Lage and Godinho 2011, Morgan and Gagnon 2013). These characteristics are briefly introduced as follows.

Uncertain timing and volume of returns: The uncertainty of timing and volume of returns are a result of a number of factors, including the life-cycle stages of a product, the rate of technological change, etc. (Östlin et al. 2009). The core availability should follow the product life cycle with a certain time lag due to product usage life. In the early stage of the life-cycle, there are few cores returned because the products are just newly introduced, and later more cores become available when increasing number of products on the market are returned (Steinhilper 1998). This characteristic is also the topic of the Research Objective 2 in this dissertation.

Need to balance returns with demand: The problem of balancing the demand with returns is also a function of a product's expected life and the rate of technical innovation. An over-stock of the cores has the risk of obsolesce, while a lack of core results in lost sales and high unit operational cost. The remanufacturers may apply different core acquisition programs (for examples, service based, deposit based, credit based, etc. see Östlin et al. 2009) at the same time from the multiple resources to improve such a balance. The balance of returns with demand is also the main objective of Core Acquisition Management.

Disassembly of returned products: Different options in product recovery need different degrees of disassembly. For remanufacturing, relatively complete disassembly is required to ensure the remanufactured product quality. The disassembly schedule can be complicated and it influences other operations such as production planning information system, and inventory control (Wiendahl et al. 1999). Several literature reviews in this topic have been conducted, such as Lee et al. (2001), Kim et al. (2007). However, disassembly is out of the scope of Core Acquisition Management in this dissertation.

Uncertainty in materials recovered from returned items: The uncertainty in materials recovered is caused by the varied core quality. This uncertainty leads to high complexity and cost for remanufacturing (Fleischmann et al. 2000; Inderfurth 2005). Common methods to control the quality of the return are inspection and sorting (Galbreth and Blackburn 2006), which are also the focus of the Research Objective 3 in this dissertation.

Requirement for a reverse logistics network: A reverse logistics network concerns how used products are collected from the customers or collection sites. It requires the decisions regarding the number and location of collection sites, incentives for returns, transportation methods, and 
third party providers. A review of the research in reverse network design can be found in Akcali et al. (2009) and Aras et al. (2010).

Complication of material match restrictions: The need to match parts is when customer requires the same returned products to be remanufactured (Guide et al. 1997; Guide and Srivastava 1998). In such a case, more complicated information system and scheduling are needed.

Stochastic routings and highly variable processing times: The stochastic processing time and stochastic routings are due to the highly varied condition of the returned cores (Guide et al. 2000). Such stochastic routing and processing time add difficulties to capacity and resource planning (Georgiadis et al. 2006), scheduling (Souza and Ketzenberg 2002) and inventory control (Inderfurth and van der Laan 2001).

\subsection{Types of remanufacturers}

There are mainly two types of remanufacturers, OEM remanufactures and Independent remanufacturers, depending on whether they remanufacture their own products. The differences between them are explained as follow.

OEM remanufacturers: OEM (Original Equipment Manufacturer) remanufacturers remanufacture their own products. They collect cores from their own customers through the sales channel, service contract, ownership of the products, etc. For example, Caterpillar and John Deere claim that their remanufactured products use all genuine parts and technology, so that they are restored to same quality standards (Caterpillar Inc. 2014; John Deere 2014). When selling new products, they are also able to charge a deposit to ensure that customers return cores with a sufficient quality.

Independent remanufacturers: Independent remanufacturers remanufacture products of other manufacturers. Compared with OEM remanufacturers, they may be limited to the access to the customers, the product knowledge, and government support. For example, the car part independent remanufacturers are not allowed to remanufacture the products of other manufacturers without their authorization in China (NDRC 2008). No that there are also independent remanufacturers that are contracted with OEMs, which are less restricted by the limitation above. Despite the above disadvantages, the independent remanufacturers are very important participants in remanufacturing industry. In the United States, the majority of remanufacturers are independent (Lund 1996).

\subsection{Supply chain relationships}

The return strategies that a remanufacturer can choose to acquire cores are often dependent on its supply chain relationships. In Östlin et al. (2008), several supply chain relationships are identified through case studies. They are introduced briefly below.

Buy-back: The remanufacturer buys the cores from the consumers, a scrap yard, a core dealer, or other parties. There are many research in Core Acquisition Management focus on this kind of return method with the decision to adjust the buy-back price (Kleber et al. 2012; Bulmus et al. 2014; Xiong and Li 2013).

Voluntary-based: The customer or other core suppliers voluntarily give the used products back to the remanufacturer. In this type of relationship, the remanufacturer can control the core acquisi- 
tion volume by disposing excess cores (van der Laan et al. 1996; Teunter and Vlachos 2002; Kiesmüller 2003).

Ownership-based: The product is owned by the manufacturer, and the customer uses the product in the forms of rental, lease or product-service offer (Aras et al. 2011; Agrawal et al. 2012).

Direct order: The customer gives the used product to the remanufacturer, and the same product is returned to the customer after being remanufactured (if possible). This kind of relationship is related with the need to match materials in Guide et al. (2000).

Deposit-based: When the customer buys a product, they are charged a specific amount of deposit. The deposit is given back to the customer depending on the quality of returned cores.

Credit-based: The customer receives a certain number of credits when returning the core. The credits can be sued as discount when buying a remanufactured product.

Service contract based: There is a contract which defines remanufacturing activities and responsibility between the manufacturer and the customer.

These supply chain relationships are not used exclusively as individual. Instead they are complemented to each other and often used in a mixed form by the remanufacturers. For examples, ownership-based and buy-back relationships are reported to be used in BT Industries, while deposit based and buyback relationships are used in Volvo Parts (Östlin et al. 2008).

\subsection{Product life cycle}

The concept of product life cycle is introduced in 1950s (Dean 1950; Dean 1951). It describes the evolution of a product, measured by its sales over time. It represents the unit sales curve for some products, extending from the time it is first placed on the market until it is removed (Rink and Swan 1979). As illustrated in Figure 6, during the product life cycle, a product will go through the phases such as introduction, growth, maturity and decline (Cox 1967).

An analytical modeling method to explain such phenomenon is the widely used Bass Diffusion model (Bass 1969). The model assumes that the consumers are classified as: innovators who are not influenced by others in the timing of their initial product purchase, and imitators whose purchasing behaviors are influenced by the number of previous buyers.

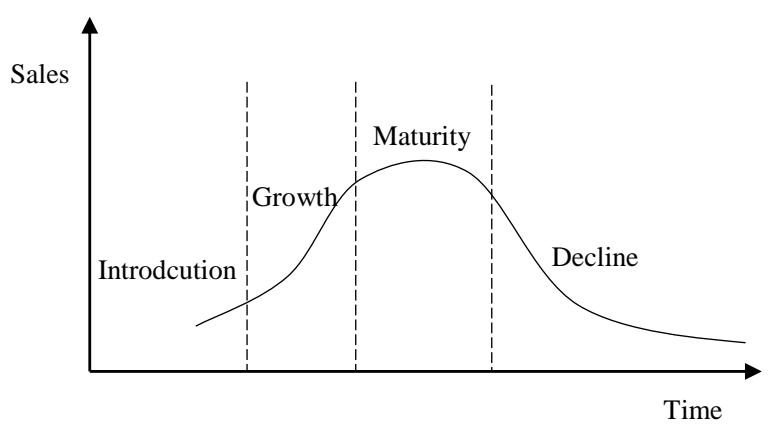

Figure 6. An illustration of the product life cycle 
The sales change in product life cycle affects the core availability with a certain time lag due to the product usage life with the customers. Such a relation is discussed in the case studies of Östlin et al. (2009) with a consideration of three categories of remanufacturing system: product remanufacturing, component remanufacturing and product cannibalization. Previous studies in Core Acquisition Management with a focus on product life cycle aspects can be seen in Debo et al. (2006), Geyer et al. (2007) and Akan et al. (2013).

\subsection{Two types of classification errors}

To understand the tradeoff of the classification errors existed in the core quality inspection process, the concepts related to binary classification are firstly explained here. Binary or binomial classification is the task of classifying the elements of a given set into two groups with a classification rule. Some typical examples are: in medical diagnosis to determine if a patient has certain disease or not; in a document classification to determine whether a given news article is about a given topic of interest or not (Ghaoui 2014).

Given a data set and a classification method (classifier), there are two numbers: the number of positives and the number of negatives. To evaluate such a classifier, the classification results are compared with a perfect classification (in practice the output of another gold standard test, since perfect classification may be difficult to achieve). The comparison can be summarized in the following two-by-two contingency table (Table 2). The following rates can be derived and they are of special interests (Roxy and Devore 2011).

Table 2. Contingency table to evaluate a classification method

\begin{tabular}{|l|l|l|}
\hline & $\begin{array}{l}\text { Positive } \\
\text { (by gold standard) }\end{array}$ & $\begin{array}{l}\text { Negative } \\
\text { (by gold standard) }\end{array}$ \\
\hline Test positive & True positive & False positive \\
\hline Test negative & False negative & True negative \\
\hline
\end{tabular}

False Positive Rate (Type I error): This is the proportion of false positive and tested positive among all actual positive.

False Negative Rate (Type II error): This is the proportion of false negative and tested negative among all actual negative.

True Positive Rate (Sensitivity): This is the proportion of true positive that is tested as positive. It relates to identify a condition correctly.

True Negative Rate (Specificity): This is the proportion of true negative that is tested as negative. It relates to the ability to exclude a condition correctly.

There is a tradeoff between the above two types of errors. Such tradeoff can be presented by the DET (Detection Error Tradeoff) curve, which is the graph plotting the two types of errors against each other on logarithmical transformed axes, or by ROC (Receiver Operating Characteristic) curve, which is the graph plotting True Positive Rate against False Positive Rate (see details in Martin et al., 1997). 
Take the core inspection process as an example, core quality can vary a lot and it also leads to very different remanufacturing costs. Some cores with good quality are economical to be remanufactured, while others of a low quality are not. In order to avoid unnecessary operational costs, early inspection is usually necessary (Tagaras and Zikopoulos 2008, Zikopoulos and Tagaras 2008). The inspection of the core quality can be carried out visually using simple classification methods, due to time and cost concerns. In such a case the inspection errors are inevitable. If positive is defined to be a returned core being classified as good enough to be remanufactured. Then false positive (type I error) will be the case that a bad quality core is inspected as remanufacturable, and false negative (type II error) will be the case that a good quality core is inspected as non-remanufacturable. 



\section{Summary of Research Results}

This chapter presents the results, included the main managerial insights of each individual paper appended in the dissertation. Later in Chapter 5, these results and contributions are further discussed.

Paper 1: Core (product) Acquisition Management for remanufacturing: a review

From the academic perspective, this paper answers RO1 of what is the current research status of Core Acquisition Management. Through the literature review, it is observed that related research interests in Core Acquisition Management have been increasing quickly recently. This literature review paper firstly discusses the concept of Core Acquisition Management, and then provides an overview about the current research status of quantitative modeling in Core Acquisition Management. The study categorizes and analyzes the collected targeted research papers, according to their key assumptions, such as hybrid/non-hybrid systems, acquisition functions (the relation between acquisition effort and acquisition volume), quality classification, perfect/imperfect assumption. Consequently, research gaps and possible further research are indicated.

Based on the analysis, it is observed that perfect substitution assumption is widely used in studying hybrid remanufacturing systems. Imperfectly substituted demand is usually described as the inverse function based on customer's willingness-to-pay model, or alternatively a fixed portion of demand is assumed to be substitutable. In addition, hybrid manufacturing/remanufacturing systems have been receiving more academic interest, even though non-hybrid systems are more often in practice.

While various assumptions about acquisition functions (the relation between acquisition effort and acquisition volume) are used, more detailed analysis and empirical work are needed to validate them under different supply chain relationships. In addition, errorless quality classification (grading) methods are usually set as predetermined, so the economic impact of the classification methods and inspection errors may be of interest both from the industrial and research perspectives.

Highlights of the insights in response to RO1:

- Research interests in Core Acquisition Management have been increasing rapidly recently;

- Most of the research in Core Acquisition Management focus on acquisition control;

- Research on return strategies, quality classifications and return forecast are still lacking;

- More research emphasis has been on the hybrid manufacturing/remanufacturing system instead of non-hybrid remanufacturing system, even though the latter one is more often in practice;

- Perfect substitution assumption is widely used in hybrid manufacturing/remanufacturing system;

- Core acquisition functions vary and their empirical validation should be investigated;

Paper 2: Motives and barriers of the remanufacturing industry in China

To gain understanding of the current status of Core Acquisition Management (RO1) from industrial perspective and to obtain the general background of the motives and barriers of remanufacturing, a survey is carried out in a fast developing remanufacturing market - China. The survey consists of three rounds of questionnaire collections through remanufacturing related conferences (exhibitions) and internet respectively, and finally 34 valid respondents are collected. 
Through this survey, the following observations are obtained, and suggestions for further developing remanufacturing industry, particularly from the policy maker's perspective, are also proposed.

In general, environmental and ethical responsibility, customer orientation and strategic advantage were top three motives. On the other hand, subsidy was the lowest ranked motive on the list and profitability was not considered as a highly ranked motive. Although market-related barriers (such as customer recognition, lack of sales channels, etc.) are very serious at present, the remanufacturers were optimistic about their improvement in the next 5-10 years. On the other hand, they were less optimistic considering the improvement of core acquisition-related barriers (core volume, core quality). The remanufacturers were also optimistic about the technologyrelated barriers (lack of technology, lack of product knowledge). The most-mentioned technology barriers were quality-related: quality standards, quality testing and control. The concept of "design for remanufacturing" was not familiar among the remanufacturers, and still needs to be further introduced.

Besides, compared with machinery remanufacturers, car part remanufacturers showed stronger motives for receiving subsidies. Regarding the barriers, car part remanufacturers were more severely restricted by legislation, whereas lack of sales channels was a more serious barrier for machinery remanufacturers.

The policy makers should be aware of the overall motives and barriers of the remanufacturers, as well as the differences between different remanufacturers. In particular, the government should consider relaxing the current restrictions on regulating car part remanufacturing, especially concerning the independent remanufacturers, who have shown to be important players in the developed markets, for example, the United States. On the other hand, the policies for machinery remanufacturers should spend more effort on improving their sales channels and providing subsidies. Building core acquisition channels/systems for remanufacturers is also important, as the remanufacturers are less optimistic about the improvement of the associated barriers in the near future.

\section{Highlights of the insights in response to RO1:}

- The barriers of core acquisition issues (core volume and core quality) are serious for the remanufacturers in China, but they are less serious as the barrier of customer recognition;

- The remanufacturers expect that the barriers of core acquisition to be less serious in recent future; however, they are more optimistic about the improvement concerning the customer's recognition.

Paper 3: Managing cores for remanufacturing during the product life cycle

This paper responds to RO2 of how to manage the uncertain return volume and timing. The core acquisition problem in this paper is set in a long-term strategic framework. During the product's life cycle, the demands for remanufactured products and the availability of cores change over time. Using optimal control theory, core acquisition and remanufacturing decisions are optimized to maximize the remanufacturer's profit over the whole product life cycle. In the objective function, the remanufacturing cost decreases with respect to core inventory, which reflects the observations from industrial practice. It is found that besides simple bang-bang type control policies 
(either collecting as much as possible, or nothing at all), synchronizing policy (adjusting the core collection rate with demand rate) also exists in between the bang-bang type policies, the results are illustrated in numerical experiments based on a component remanufacturing scenario.

In the numerical experiments, the influences of various factors in product life cycles are investigated, such as core source compositions, product life length, core price changes, etc. The numerical experiments show that the remanufacturer starts collecting as many cores as possible from the beginning unless the core collecting price is very high. While in the end of the product life cycle, the time to stop collecting can be very different, depending on how fast the remanufacturing cost decreases with the core inventory. Concerning remanufacturing, in the beginning there is a period during which no demand is met, in order to build up inventory for reducing remanufacturing costs later. Once all demands start to be met, the remanufacturer should always meet as much of the demand as possible. It should be noticed that such patterns can be affected due to the change of the core collecting price. For example, when the collecting price is decreasing linearly, there may exist a period in the beginning where no cores are collected at all if the core collecting price is too high.

The time to stop collecting is not affected much by the return rate of disposed products, while the cores from failed parts are more important at balancing the relationship between demand and core availability. The product life length affects the time to dispose of used products in the later stages of the product life cycle. As a result, product life length has more impact on the time to reduce and stop collecting, and have less impact on the time to start remanufacturing and to fully meet demand.

Highlights of the insights in response to RO2:

- Besides simple bang-bang type control policies (either collecting as much as possible, or nothing at all), synchronizing policy (adjusting the core collection rate with demand rate) also exists;

- Cores from failed parts are more important at balancing the relationship between demand and core availability;

- The remanufacturer should start collecting as many cores as possible from the beginning unless the core collecting price is very high;

- The time to stop collecting can be very different, depending on the product life length, and how fast the remanufacturing cost decreases with the core inventory.

Paper 4: Real option approach to evaluate cores for remanufacturing in service markets

The decision of acquisition effort depends greatly on how the core is evaluated. Real Option Valuation approaches are used in this paper to capture the value of production flexibility provided by cores with the presence of uncertain product price, uncertain demand and return volume. The study results help us gain a better knowledge regarding $\mathrm{RO} 2$.

In a system with a low demand volume and the product price being the major uncertain issue, core value is presented in a closed form formula using a call option principle. Furthermore, based on the binominal tree approach, the value of early disposing the core before demand is investigated. It is shown in numerical experiments that the advantage of salvaging early and reducing additional holding costs can be obtained only when decision horizon (expiration time) is long, holding cost and salvage value are high, and the product price is low. 
In order to analyze the uncertain with large volume demand and return, we apply the spread option principle to present the marginal value of stocking cores. This approach provides the advantage of describing the correlation between demand and return. According to the numerical experiments, an increasing correlation between demand and return has a positive impact on the marginal value of the core when inventory level is low, while this impact becomes negative when inventory level is high. In practice, this implies that given a relatively low core price, the remanufacturer should collect more cores when correlation between demand and return is higher; while given a high core price, the remanufacturer should collect less cores if such correlation is high. In addition, the volatility of demand (return) should improve the value of cores only if demand (return) volume dominates return (demand) volume.

Highlights of the insights in response to RO2:

- The advantage of disposing a core earlier, by salvaging and reducing holding costs can be obtained only when demand comes very late, holding cost and salvage value are high, and the product price is low;

- Given a relatively low core price, the remanufacturer should collect more cores when correlation between demand and return is higher; while given a high core price, the remanufacturer should collect less cores if such correlation is high;

- The volatility of demand (return) should improve the value of cores only if demand (return) volume dominates return (demand) volume.

Paper 5: Refund policies for cores with quality variation in OEM remanufacturing

To deal with the problem about uncertain quality of returned cores (RO3), in this paper we develop models for the commonly used refund policies. These refund policies include single refund, multiple refund and perfect refund policies, depending on the number of their quality classifications. With the assumption that the quality of cores is uniformly distributed, we derive analytical solutions for the refund policies. Furthermore, propositions are introduced to decide the partition of the quality classes in the multiple refund policy.

Utilizing the analytical results above, we conduct numerical experiments to compare the performances of these refund policies, and the influences of customers' valuation of cores and demand sensitivity. Compared with single refund policy, multiple refund policy provides the opportunity to screen out low quality cores. The gaps between different refund policies decrease as demand sensitivity increases and when customers' valuation of the cores is high. Increasing the number of quality classifications brings in more benefit, but the marginal improvement decreases as the number gets larger. As a result, a relatively small number of quality classes is suggested in order to capture the major benefit of the multiple refund policy and in the meantime avoid the unnecessarily high administration costs.

Compared with credit policies where no deposit is charged, refund policies are better if the demand sensitivity is not too high. Besides, customers' valuation of cores is an essential factor that affects the performances. If the customers' valuation of cores is high, the refund policy has more opportunities to be implemented than the credit policy, even with the relatively high demand sensitivity. Such a policy should receive more attention when the market competition for collecting cores is high. 
We also show in the numerical experiments that how the partition of the quality classes could be different if the quality subjects to a more general adjusted normal distribution. The advantage of using accurate quality partitions, rather than simply applying the partition of uniformly distributed quality, is larger when the customers' valuation of the cores is high. Again such a concern is more important in a competitive core market.

Highlights of the insights in response to RO3:

- Compared with single refund policy, multiple refund policy provides the opportunity to screen out low quality cores;

- A relatively small number of quality classes is suggested in order to capture the major benefit of the multiple refund policy and in the meantime avoid the unnecessarily high administration costs;

- Compared with credit policies where no deposit is charged, refund policies are better if the demand sensitivity is not too high;

- If the customers' valuation of cores is high, the refund policy has more opportunities to be implemented than the credit policy;

- The advantage of using accurate quality partitions, instead of applying the simple partition of uniformly distributed quality, is larger when the customers' valuation of the cores is high. Such an advantage is more important in a competitive core market.

Paper 6: Refund polices and core classification errors in the presence of customers' choice behavior in remanufacturing

This research paper continues responding to RO3 after paper 5, by considering more detailed classification errors and customer's behaviors within a game theory framework. In this paper it is observed that the customer's access to the information of inspection errors is very important. When the customer has the access to the information of the inspection errors, there are four possible pure strategies for describing the customer's return behavior. The equilibrium depends on the remanufacturer's choices of inspection errors and deposit. The conditions for when each pure strategy will be used and when it is reachable are developed. Further we analyze the remanufacturer's optimal profits under each pure strategy, and present a solution procedure for choosing the combination of deposit value and inspection errors from the remanufacturer's perspective.

When the customer does not have the information of the inspection errors, i.e., when the inspection errors are not announced by the remanufacturer, the customer will possibly use mixed strategies for returning low quality cores. In this case the solution and conditions are also developed, given that the deposit is decided already and the customer has already obtained the product.

It is also shown numerically that lacking of inspection error information will reduce the profit for the remanufacturer, thus it is important to improve such information transparency. To achieve a high information transparency, the remanufacturer should chose quality inspection criteria carefully and state the inspection error clearly if possible.

The remanufacturer should also pay special attention to the value structure of the cores and the products. More specifically, the difference of salvage values between high quality and low quality cores determines whether it is possible to collect only high quality cores, which in turn affects the remanufacturer's decision of the inspection error. The estimation of the product's payoff to the customer is another key factor that influences the remanufacturer's choices of the inspection error and deposit. A relatively conservative estimation (underestimation) of such a value reduces 
the total profit, but it also maintains some of the remanufacturer's profit even if the wrong value of such a payoff is used to a certain extent.

Notice that the studies in Papers 5 and 6 regarding quality classification are based on the assumption of a deposit-refund collection relationship. With proper adjustments, however, the principles derived can be generalized to other types of relations as well, such as credit based and buyback ones.

Highlights of the insights in response to RO3:

- When the customer has the access to the information of the inspection errors, there are four possible pure strategies regarding the customer's return behavior;

- When the customer does not have the information of the inspection errors, the customer will possibly use mixed strategies for returning low quality cores;

- Lacking of inspection error information will reduce the profit for the remanufacturer, so it is important to improve such information transparency;

- To achieve a high information transparency, the remanufacturer should chose quality inspection criteria carefully and state the inspection error clearly if possible;

- The difference of salvage values between high quality and low quality cores determines whether it is possible to collect only high quality cores, which in turn affects the remanufacturer's decision of the inspection error;

- The underestimation of customer's product payoff reduces the remanufacturer's profit, but such profit is more secure to some extent. 


\section{Conclusions}

Core Acquisition Management actively attempts to manage the uncertainties in the return process, in terms of return volume, timing and core quality, therefore achieving a better balance between return and demand, as well as a more efficient remanufacturing process. It is essential to the success of remanufacturing business. The aim of this dissertation is to extend the knowledge about Core Acquisition Management by investigating the current status of research and industrial practice, and developing quantitative models that assist decision making in the core acquisition process in remanufacturing. According to this research aim, the following three research objectives are formulated.

RO1: Identifying research gaps and industrial needs in Core Acquisition Management;

RO2: Developing models for core acquisition decisions to manage return volume and timing uncertainties;

RO3: Developing models for core acquisition methods to manage the uncertainty of core quality.

The scientific contributions regarding the above three research objectives are summarized respectively in Section 5.1 below. Further research directions are suggested in Section 5.2.

\subsection{Discussion and contribution}

\section{RO1: Current status of research and industry practice in Core Acquisition Management}

Due to its practical importance in, the term of Core (product) Acquisition Management was firstly formally brought up by Guide and Jayaraman (2000). Recently it has been receiving more and more research interests as shown by the literature review in Paper 1. This literature review focuses specifically in quantitative research in Core Acquisition Management, which has not been conducted systematically before.

In this review, the activities in Core Acquisition Management are summarized and categorized based on previous studies of Guide and Jayaraman (2000), Atasu et al. (2008) and Souza (2013). It is observed that there is a lack of research about return forecast and the choices of return strategies. In addition, there are varied assumptions about the acquisition function (the relation between acquisition effort and return volume). The empirical validations of these assumptions are imperative, and more studies based on imperfect substitution assumption are welcome. Generally it is found that the researchers are more in favor of model complexity, for example, the hybrid manufacturing/remanufacturing system with perfect substitution assumption, while the problems in more common practical settings, such as the non-hybrid remanufacturing system and the imperfect substitution, receive relatively less attention. Such observation is also in line with the descriptions in Guide and Wassenhove (2009): "many assumptions, such as perfect substitution, are rapidly becoming institutionalized, and this can reduce modeling efforts to elegant solutions addressing nonexistent problems."

Regarding the current status of Core Acquisition Management in practice, a descriptive survey is conducted in a China. A better understanding of the Chinese remanufacturing industry is important, due to its great economic potential and environmental impact. Previous studies in Chinese remanufacturing industry are lacking of empirical data (Zhang et al. 2011; Xiang and Ming 
2011). Through the survey of Paper 2 among the remanufacturers in China about their motives and barriers, it is interesting to find that environmental and ethical responsibility, customer orientation and strategic advantages are among the most important motives in China, while the most serious barrier overall is customer recognition, which is more serious than core acquisitionrelated barrier (core volume and core quality). Some of the results are quite different compared with other countries. For example, while customer recognition is the most serious barrier in China at present, operational issues such as high cost and complexities are more serious in Greece (Kapetanopoulou and Tagaras 2010), Sweden (Sundin et al., 2005) and Finland (Guidat et al., 2014). In addition, car part remanufacturers are strongly regulated by Chinese government, regarding the barrier of legislation restriction and the motive for subsidies.

Different motives and barriers will possibly lead to different management approaches, including Core Acquisition Management. The study does not only provide suggestions directly to remanufactures and policy makers, but also help researchers in remanufacturing area to formulate their research objectives and assumptions in a way that is more aligned with remanufacturing practice.

\section{RO2: Modeling to deal with the uncertain return volume and timing}

The demand and core availability, as well as core acquisition price change during the product life cycle, therefore the dynamic control of core acquisition becomes important. Such a problem has been studied previously such as in Minner and Kiesmüller (2012) and Kleber et al. (2012). In these research, the unit remanufacturing cost is usually set as constant. Paper 3 contributes to this stream of research by considering a realistic remanufacturing cost structure from practical observation. For the remanufacturer, the unit remanufacturing cost tends to increase with less cores in inventory, because that the cores with lower quality have to be used to satisfy the demand, sometimes expensive tooling or even buying new product have to be considered (Schinzing 2010). Such cost structure is very different with traditional manufacturing, where the quality of supply is usually good and less uncertain. This cost structure encourages the remanufacturer to build up and keep more inventory of cores. Furthermore, the collecting policy besides simple bang-bang strategy is also different, as suggested by Paper 3.

Other than the direct optimization of core acquisition volume as in Paper 3, Paper 4 helps core acquisition decision by developing models to evaluate the cores properly. Using real option principles, the cores are viewed as a valuable resource that provides the flexibility to deal with the uncertainties in terms of product price, demand and return volume. There are limited applications of real option valuation methods in remanufacturing research area so far. Liang et al. (2009) describe the uncertain market price of the remanufactured products as following Geometric Browning Motion, and then evaluate the cores when the remanufactured product can be sold at a prescribed price. Shi and Min (2014) focus on the value of core with uncertainty core quality. The remanufacturers can decide to dispose or remanufacture a core depending on its observed cost. Paper 4 contributes the applications of real option valuation in remanufacturing related research in the following aspects. Firstly, in a remanufacturing system with a low volume, slow moving item, the value of earlier disposition is shown when product price is uncertain. Secondly in a fast moving remanufacturing setting, the value of a core is considered when both the uncertainties of demand and return are included. In this case, the impacts of the correlation between demand and return depend very much on the inventory of cores. 
In addition, neither the methods in Paper 3 nor Paper 4 are limited in a hybrid manufacturing/remanufacturing system with the perfect substitution assumption, which are very common settings in Core Acquisition Management research. However, non-hybrid remanufacturing systems and imperfect substitution between new and remanufactured product are more common in practice.

\section{RO3: Modeling development to deal with the uncertain core quality}

Papers 5 and 6 contribute to the Core Acquisition Management research by considering two quality classification problems that have not been addressed specifically. The partition of quality classification and the tradeoff of two types of classification errors, in a deposit-refund return strategy.

Despite the increasing interests in Core Acquisition Management research, the studies focus on quality classification methods, i.e. how the cores are classified into different categories, are relatively limited. Most research assume that the quality classification methods are predetermined, and the problem remained is to determine how many cores to acquire in each quality class (Teunter and Flapper 2011; Nenes and Nikolaidis 2012). Paper 5 contributes to this stream of research by investigating how such quality classification should be made, and consequently how to set the deposit and refund values.

Paper 6 further focuses on the influences of the errors in the classification procedures on the customers' return behavior, and how the remanufacturer should react based on the customers' possible responses. This problem is similar to the inspection game (Avenhaus et al. 2001), which has been studied in areas like arms control (Altman et al.1992), environmental control (Guth and Pethig 1992), accountancy and auditing (Borch 1990). However, such issue has not been closely examined in remanufacturing core collecting procedure. Existing research study focuses on one type of classification error (Van Wassenhove and Zikopoulos (2010), or two types of classification errors that are independent (Tagaras and Zikopoulos 2008; Zikopoulos and Tagaras 2008). Considering the tradeoff of the two types of classification errors, as well as the remanufacturer's active choice of such errors are the contribution of Paper 6 in Core Acquisition Management research.

In addition, Papers 5 and 6 are set in a deposit-refund return strategy. Such a return strategy is commonly used for controlling returns (Guide and Jayaraman 2000), yet the related studies are relatively limited. Both Paper 5 and Paper 6 extend the knowledge for this return strategy.

\section{Summary of contribution}

In conclusion, this dissertation contributes to the knowledge in Core Acquisition Management research area in terms of both understanding the current status, and developing new modeling techniques.

For the current status of research, a literature review is conducted and further research suggestions are indicated accordingly, while for the current status of practice, the main motives and barriers are identified in a fast developing remanufacturing market - China. Understanding these knowledge is important for the researchers to formulate their studies in a more industry-relevant way. It can also help the government to make proper policies to develop the remanufacturing industry. 
Regarding the modeling techniques, firstly, several new research problems are brought up and investigated. The dynamic control of core acquisition is studied in a product life cycle setting, where remanufacturing cost decreases with core inventory. The valuation methods of cores in an uncertain remanufacturing environment are developed to aid the core acquisition decisions. To manage the uncertain core quality, the classification methods and the tradeoff of the classification errors are studied in a deposit-refund return strategy. These new research problems are formulated based on the observations from industry practice. The managerial insights from these research could help understanding the existed phenomenon in remanufacturing business, and potentially serve the practitioners as decision-making tools as well. Academically, they also enrich the body of research in Core Acquisition Management, and may also provide further research interests. The modeling approaches used in this dissertation, such as optimal control, real option valuation, game theory, could also help the research in Core Acquisition Management from a methodological viewpoint.

\subsection{Further research}

The coverage of Core Acquisition Management area is very wide, and there are many interesting research topics that deserve further investigation. As indicated by the literature review study in this dissertation, return strategies and the forecast of return are also very important issues in Core Acquisition Management, yet related studies are still relatively limited. In the following, several interesting research problems are introduced, based on the studies from the included papers.

In the empirical survey conducted in China (Paper 2), further validations through interviews and larger scale surveys are needed to confirm some of the observations and their reasons. For examples, why environmental and ethical responsibility is considered as one of the most important motives in remanufacturing? Why lack of sales channels is of different importance as the barriers for car part remanufacturer and machinery remanufacturers? In addition, the remanufacturing industry in China is developing rapidly, as well the related government policies are changing swiftly. In this case, will the motives and barriers be evolved in several years? Comparison study between different regions could also be an interesting topic.

One of the key information in the Core Acquisition Management is the estimation of return and demand. When more accurate estimation is possible, the technique used in the acquisition planning model (Paper 3) are more appropriate, otherwise core valuation approaches with real option principle (Paper 4) can be used. However, how to obtain the required estimation from historical data and how to estimate when there is not enough historic data available, are still fundamental problems that deserve attentions. New forms of core transactions, such as internet biding (eBay), and third party core supply information platform (Core pricing.com) are becoming more popular. These pricing mechanisms and their implications for remanufacturers' acquisition decisions are also of great interest.

In modeling of quality classification and inspection problems, relatively simple assumptions are made about the quality distribution for the purpose of mathematical tractability. Various quality distributions of the core quality can be further studied by using the similar modeling approaches developed in this dissertation. Combining the problem of quality classification and the problem of choosing inspection errors will definitely add more complexity of the analysis, but it may worth the effort for investigation. 
It will also be interesting to verify the managerial principles derived from the above analytical models, and how they can be applied in real-life cases. During the verification and application process, it is expected that a number of further questions can be brought up. 



\section{References}

Agrawal V. V., Ferguson M., Tokttay L. B., Thomas V. M., 2012, Is leasing greener than selling? Management Science, 58, 3, 523-533.

Akan M., Ata B., Savaskan-Ebert R. C., 2013, Dynamic pricing of remanufacturable products under demand substitution: a product life cycle model. Annals of Operations Research, 211,1-25.

Akcali E., Cetinkaya S., Uster H., 2009, Network design for reverse and closed-loop supply chains: an annotated bibliography of models and solution approaches. Networks, 53, 3, 231-248.

Altmann J., 1992, Verification at Viennna: Monitoring reductions of conventional armed forces, Gordon and Breach, Philadelphia.

Aras N., Boyaci T., Verter V., 2010, Designing the reverse logistics networks, in M. Ferguson and G. Souza (Eds.), Closed-loop supply chains: new developments to improve the sustainability of business practices. Boca Raton, FL: CRC Press, 23-38.

Aras N., Gullu R., Yurulmez S., 2011, Optimal inventory and pricing policies for remanufacturable leased products. International Journal of Production Economics, 133, 1, 262-271.

Arden P. C. et al., 2002, Cancer, cardiopulmonary mortality, and long-term exposure to fine particulate air pollution. Journal of American Medical Association, 287 9, 1132-1141. doi:10. 1001/jama.287.9.1132. PMID 11879110.

Atasu A., Guide V. D. R., Van Wassenhove L. N., 2008, Product reuse economics in closed-loop supply chain research. Production and Operations Management 17, 5, 483-496.

Avenhaus R., Stengel V. B., Zamir S., 2003, Inspection Games, Handbook of Game Theory with Economic Applications, 3, 1947-1987.

Bass F., 1969, A new product growth model for consumer durables. Management Science, 15, 215-227.

Becerra M., 2008, Scholarpedia, 3, 1:5354, doi:10.4249/scholarpedia.5354

Bengtsson J., 2001, Manufacturing flexibility and real options: a review. International Journal of Production Economics, 74, 213-224.

Bengtsson J., Olhager J., 2002a, Valuation of product-mix flexibility using real options. International Journal of Production Economics, 78, 13-28.

Bengtsson J., Olhager J., 2002b, The impact of the product mix on the value of flexibility. Omega, The International Journal of Management Science, 30, 265-273.

Berling P., 2008, Real options valuation principle in the multi-period base-stock problem. Omega, The International Journal of Management Science, 36, 6, 1086-1095.

Black F., Scholes M., 1973, The pricing of option and corporate liabilities. Journal of Political Economy, 81, 637-654. 
Borch K., 1990, Economics of Insurance. Advanced Textbooks in Economics. Vol. 29, NorthHolland, Amsterdam.

Borison A., 2005, Real Options Analysis: where are the Emperor's Clothes? Journal of Applied Corporate Finance, 17, 2, 17-31.

Bulmus S. C., Zhu S. X., Teunter R., 2014, Competition for cores in remanufacturing. European Journal of Operational Research, 233, 105-113.

Cachon G., Netessine S., 2004, Game theory in supply chain analysis, David Simchi-Levi, S. David Wu, Zuo-Jun (Max) Shen (Eds.), Handbook of Quantitative Supply Chain Analysis: Modeling in the eBusiness Era, Kluwer.

CARDONE industries, 2014, Remanufacturing: the ultimate sustainability solution. Available: http://www.cardone.com/docs/environmental-commitment/Reman-Ultimate-Form-of-Recycling. pdf

Caterpillar Inc., 2014, Core Acceptance Criteria. Available: http://china.cat.com/en/parts-andservices/reman/core, Last accessed 6th Apr 2014.

Cesaroni G., Forastiere F., Stafoggia M., et al., 2014, EU's PM2.5 Limit Festering: New Study Linked PM with Heart Attack "Long term exposure to ambient air pollution and incidence of acute coronary events: prospective cohort study and meta-analysis in 11 European cohorts from the ESCAPE Project.". BMJ (Clinical research ed.) 348. doi:10.1136/bmj.f7412. PMID 24452269.

Ceseña E. A. M., Mutale J., Dávalos F. R., 2013, Real options theory applied to electricity generation projects: a review. Renewable and Sustainable Energy Reviews, 19, 573-581.

Chapman A., Barlett C., McGill I., Parker D., Walsh B., 2009, Remanufacturing in the UK: a snapshot of the remanufacturing industry in the UK in 2009. Center for Remanufacturing and Reuse.

Cox Jr. W. E., 1967, Product life cycles as marketing models. Journal of Business, 40:4.

Cummins Inc., 2014, Remanufacturing. Available: http:/www.cummins.com/global-impact /sustainability/environment/products/remanufacturing.

Dean J., 1950, Pricing policies for new products. Harvard Business Review, 28, 45-53.

Dean J., 1951, Managerial Economics, Prentice-Hall, Inc. Englewood Cliffs

Debo L. G., Toktay L. B., Van Wassenhove L. N., 2006, Joint life-cycle dynamics of new and remanufactured products. Production and Operations Management, 15, 498-513.

Denizel M., Ferguson M., Souza G., 2010, Multi-period remanufacturing planning with uncertain quality of inputs. IEEE Transactions on Engineering Management, 57, 3, 394-404.

Fernandes B., Cunha J., Ferreira P., 2011, The use of real options in energy sector investments. Renewable and Sustainable Energy Reviews, 15, 9, 4491-4497. 
Filippini R., 1997, Operations management rsearch: some reflection on evolution, models and empirical studies in OM. International Journal of Operations and Production Management, 17, 655-670.

Fleischmann M., Bloemhof-Ruwaard J. M., Dekker R., van der Laan E. A., Van Nunen J. A. E. E., Van Wassenhove, L. N., 1997, Quantitative models for reverse logistics: a review, European Journal of Operations Research, 103. 1-13.

Fleischmann M., Krikke H. R., Dekker R., Flapper S. D. P., 2000, A characterisation of logistics networks for product recovery. Omega, 28, 6, 653-666.

Galbreth M. R., Blackburn J. D., 2006, Optimal acquisition and sorting policies for remanufacturing. Production and Operations Management, 15, 384-392.

Georgiadis P., Vlachos D., Tagaras G., 2006, The impact of product lifecycle on capacity planning of closed-loop supply chain with remanufacturing. Production and Operations Management, $15,4,514-527$.

Geyer R, Van Wassenhove L. N., Atasu A., 2007, The economics of remanufacturing under limited component durability and finite product life-cycles. Management Science. 53:88-100.

Ghaoui L. E., UC Berkeley, 2014, Optimization Models and Applications, available at https://inst.eecs.berkeley.edu/ ee127a/book/login/index.html, retrieved on November 15th, 2014

Global Energy Statistical Year Book, 2014, http://yearbook.enerdata.net/, retrieved on October 5th, 2014.

Guidat T., Uoti, M., Tonteri H., Määttä T., 2014, A classification of remanufacturing networks in Europe and their influence on new entrants. Presented at the 12th Global Conference on Sustainable Manufacturing, Malaysia, to be published in Procedia CIRP.

Guide V. D. R., 2000, Production planning and control for remanufacturing: industry practice and research needs. Journal of Operations Management. 18, 467-83.

Guide V. D. R., Jayaraman V., 2000, Product acquisition management: current industry practice and a proposed framework. International Journal of Production Research, 38, 3779-3800.

Guide V. D. R., Jayaraman V., Srivastava R., Benton W. C., 2000, Supply chain management for recoverable manufacturing systems. Interfaces. 30, 3, 125-142.

Guide V. D. R., Srivastava R., 1997, Buffering from material recovery uncertainty in a recoverable manufacturing environment. Journal of Operational Research society, 48, 519-529.

Guide V. D. R., Srivastava R., 1998, Inventory buffers in recoverable manufacturing. Journal of Operations management, 16, 4, 551-568.

Guide V. D. R., Srivastava R., Spencer M., 1997, An evaluation of capacity planning techniques in a remanufacturing environment. International Journal of Production Research, 32, 8, 1857 1866. 
Guide V. D. R., Van Wassenhove L. N., 2001, Managing product returns for remanufacturing. Production and Operations Management, 10, 142-154.

Guide V. D. R., Van Wassenhove L. N. 2009, The evolution of closed-loop supply chain. Operations Research, 57, 1, 10-18.

Guth W., Pethig R., 1992, Illegal pollution and monitoring of unknown quality - a signaling game approach. In: Conflicts and Cooperation In Managing Environmental Resources, Springer, Berlin, 276-332.

Hatcher G. D., Ijomah W. L., Windmill J. F. C., 2011, Design for remanufacture: a literature review and future research needs. Journal of Cleaner Production, 19, 2004-2014.

Hull J. C., 2005, Options, Futures and Other Derivatives, 6th edition, Prentice-Hall.

Inderfurth K., 2005, Impact of uncertainties on recovery behavior in a remanufacturing environment: a numerical analysis. International Journal of Physical Distribution and Logistics Management, 16, 5, 625-645.

Inderfurth K., van der Laan E., 2001 Leadtime effects and policy improvement for stochastic inventory control with remanufacturing. International Journal of Production Economics, 71, 381390.

John Deere, 2014, http://www.deere.com/en_US/parts/reman_parts_components/reman.page? retrieved on October 7th, 2014.

Kaiman J., 2014, China says more than half of its groundwater is polluted, http://www.the guardian.com/environment/2014/apr/23/china-half-groundwater-polluted, retrieved on October 2nd, 2014.

Kapetanopoulou P., Tagaras G., 2010, Drivers and obstacles of product recovery activities in the Greek industry. International Journal of Operations and Production Management, 31, 148-166.

Karlsson C., 2009, Researching Operations Management, Taylor \& Francis, New York.

Kester W. C. 1993, Turning growth options into real assets, Capital Budgeting under Uncertainty, ed. R. Aggarwal. Prentice-Hall.

Kiesmüller G. P., 2003, A new approach for controlling a hybrid stochastic manufacturing system is reverse logistics environment. Computer and Industry Engineering, 51, 2, 279-287.

Kim H. J., Lee D. H., Xirouchakis P., 2007, Disassembly scheduling: literature review and future research directions. International Journal of Production Research, 45, 18-19, 4465-4484.

Kleber R., Schulz T., Voigt G., 2012, Dynamic buy-back for product recovery in end-of-life spare parts procurement. International Journal of Production Research, 50, 1476-1488.

Lage M., Godinho M., 2012, Production planning and control for remanufacturing: literature review and analysis. Production Planning \& Control, 23, 419-435. 
Lander D. M., Pinches G. E., 1998, Challenges to the practical implementation of modeling and valuing real options. The Quarterly Review of Economics and Finance, 38, special issue, 537567.

LaValle S. M., 2006, Concerns regarding game theory in Planning Algorithms, Cambridge University Press. Available at http://planning.cs.uiuc.edu/node475.html, retrieved on December 9, 2014.

Lee D. H. Kang J. G., Xirouchakis P., 2001, Disassembly planning and scheduling: review and futhre research. Proc. Inst. Mech. Eng.: J. Eng. Manuf. - Part B, 215, 695-170.

Liang Y., Pokharel S., Lim G. H., 2009, Pricing used products for remanufacturing. European Journal of Operational Research, 193, 393-305.

LMI Inc., 2014, Go Green with LMI, available at http://www.lmisolutions.com/environment /remanufacturing-benefits, retrieved on November 20th, 2014,

Lund R. T., 1984, Remanufacturing. Technology Review, 87, 18-23.

Lund R. T., 1996, The Remanufacturing Industry: Hidden Giant, Boston, Massachusetts: Boston University.

Lundmark P., Sundin E., Björkman M., 2009, Industrial Challenges within the Remanufacturing System. Proceedings of Swedish Production Symposium, Stockholm, Sweden, 132-138.

Malhotra M. K., Grover V. 1998, An assessment of survey research in POM: from constructs to theory. Journal of Operations Management, 16, 407-425.

Martin A., Doddington G, Kamm T., Ordowski M., Przybocki M., 1997, The DET curve in assessment of detection task performance. Proc. Eurospeech '97, Rhodes, Greece, Vol. 4. pp. 1899-1903.

McDonald R. L., Siegel D. R., 1984, Option pricing when the underlying asset earns a belowequilibrium rate of return: a note. The Journal of Finance, 39, 1, 261-265.

McDonald R. L., Siegel D. R., 1985, Investment and the valuation of firms when there is an option to shut down. International Economic Review, 26, 2, 331-349.

Ministry of Environment Protection, http://english.mep.gov.cn/, retrieved on October 5th, 2014.

Minner S, Kleber R., 2001, Optimal control of production and remanufacturing in a simple recovery model with linear cost functions. OR Spektrum, 23, 3-24.

Minner S., Kiesmller G. P., 2012, Dynamic product acquisition in closed loop supply chains. International Journal of Production Research, 50, 2836-2851.

Morgan S. D., Gagnon R. J., 2013, A systematic literature review of remanufacturing scheduling. International Journal of Production Research, 51, 16, 4853-4879. 
Myerson R. B., 1991, Game Theory: Analysis of Conflict, Harvard University Press, p. 1. Chapter-preview links, pp. vii-xi.

Nash J. F., 1950, Equilibrium Points in N-Person Games. Proceedings of the National Academy of Sciences of the United States of America, 36, 48-49.

Nasr N., Hughson C., Varel E., Bauer R., 1998, State-of-the-art assessment of remanufacturing technology-draft document. Rochester Institute of Technology, National Center for Remanufacturing, Rochester, NY.

National Development and Reform Commission (NDRC), 2008, Administrative Measures for Pilot Remanufacturers of Automobile Components. http://hzs.ndrc.gov.cn/newfzxhjj/zcfg /200810/W020081006621779959214.pdf, retrieved on October 7th, 2014.

Nenes G., Nikolaidis Y., 2012, A multi-period model for managing used product returns. International Journal of Production Research, 50, 1360-1376.

Neumann J. V., 1928, “Zur Theorie der Gesellschaftsspiele”, Mathematische Annalen 100 (1): 295-320, doi:10.1007/BF01448847 English translation: Tucker, A. W.; Luce, R. D., eds. (1959), "On the Theory of Games of Strategy", Contributions to the Theory of Games 4, pp. 13-42.

Roxy P., Devore L., 2011, Statistics: The Exploration and Analysis of Data. Cengage Learning. pp. 464-465.

Pei M., 2014. China's soil pollution: It's much worse than you think, http://fortune.com/2014 /04/18/chinas-soil-pollution-its-much-worse-than-you-think/, retrieved on October 2, 2014.

Pinsonneault A., Kraemer K. L., 1993, Survey research methodology in management information system: an assessment. Journal of Management Information Systems, 10, 2, 75-106.

Pontryagin L. S., Boltyanskii V. G., Gamkrelidze R. V., Mishenko E. F., 1962, The mathematical theory of optimal processes, Wiley, New York.

Rasmusen E., 2007, Games and Information, 4th ed. Description and chapter-preview

Rea L. M., Parker R. A., 1992, Designing and Conducting Survey Research, San Rrancisco, CA: Jossey-Bass.

Rink D. R, Swan J. E., 1979, Product life cycle research: a literature review. Journal of Business Research, 219-242.

Rubio S., Chamorro A., Miranda F. J., 2008, Characteristics of the research on reverse logistics (1995-2005). International Journal of Production Research, 46, 1099-1120.

Savaskan R. C., Van Wassenhove L. N., 2006, Reverse channel design: the case of competing retailers. Management Science, 52, 1-14.

Savaskan R. C., Bhattacharya S., Van Wassenhove L. N., 2004, Closed-loop supply chain models with product remanufacturing. Management Science, 50, 239-252 
Schinzing R., 2010, Cores-Cores-Cores. Available: http://e-reman.com/blog/cores-cores-cores/, retrieved on 21st November, 2013.

Seitz A., 2007, A critical assessment of motives for product recovery: the case of engine remanufacturing. Journal of Cleaner Production, 15, 11-12, 1147-1157.

Sethi S. P., Thompson G. L., 2000, Optimal Control Theory: Applications to Management Science and Economics. 2nd Edition: Springer.

Shi W., Min K. J., 2013, Product remanufacturing: a real options approach, IEEE Transactions on Engineering Management. In Press, DOI: 10.1109/TEM.2013.2278533

Shields P., Rangarjan, N., 2013, A Playbook for Research Methods: Integrating Conceptual Frameworks and Project Management. Stillwater, OK: New Forums Press. See Chapter 4 for an in-depth discussion of descriptive research

Souza G. C., Ketzenberg M. E., 2002, Two-stage make-to-order remanufacturing with servicelevel constraints. International Journal of Production Research, 40, 2, 477-493.

Souza G. C. 2013, Closed-loop supply chains: a critical review, and future research. Decision Sciences, 44, 7-38.

Steinhilper R., 1998, Remanufacturing: the ultimate form of recycling: Fraunhofer IRB Verlag.

Sundin E., 2004, Product and Process Design for Successful Remanufacturing, Dissertation No. 906, Linköping University, Linköping, Sweden.

Sundin E., Tang O., Mårtén E. 2005, The Swedish Remanufacturing Industry - An Overview of Present Status and Future Potential, Proceedings of CIRP Life Cycle Engineering Seminar -12th edition- 2005, Paper BM4 on the LCE-05 CD, Laboratoire 3S, Grenoble, France, April 3-5.

Tagaras G., Zikopoulos C., 2008, Optimal location and value of timely sorting of used items in a remanufacturing supply chain with multiple collection sites. International Journal of Production Economics, 115, 424-432.

Taylor D, 2014, The literature review: a few tips on conducting it, Health Sciences Writing Centre, http://www.writing.utoronto.ca/advice/specific-types-of-writing/literature-review, retrieved on October 6th, 2014.

Teunter R. H., Flapper S. D. P., 2011, Optimal core acquisition and remanufacturing policies under uncertain core quality fractions. European Journal of Operational Research, 210, 241-248.

Teunter R. H., Vlachos D., 2002, On the necessity of a disposal option for returned items that can be remanufactured. International Journal of Production Economics, 75, 3, 257-266.

The University of Wisconsin-Madison Writing Center, 2009, The Writer's Handbook: Learn How to Write a Review of Literature. http://www.wisc.edu/writing/Handbook/Reviewof Literature.html, retrieved on October 5th, 2014. 
Thierry M., Salomon M., van Nunen J., Van Wassenhove L., 1995, Strategic issues in product recovery management. Californian Management Review, 37, 2, 114-135.

Trigeorgis L., 2000, Real Option: Managerial Flexibility and Strategy in Resource Allocation, the MIT Press, first Edition.

University of California Santa Cruz, Write a Literature Review, http://guides.library.ucsc.edu/ write-literature-review, retrieved on October 6th, 2014.

van der Laan E., Dekker R., Salomon M., 1996, Product remanufactuirng and disposal: a numerical comparison of alternative control strategies. International Journal of Production Economics, 45, 489-498.

Van Wassenhove, L. N., Zikopoulos C., 2010, On the effect of quality overestimation in remanufacturing. International Journal of Production Research, 48, 5263-5280.

Wiendahl H. P., Seliger G., Perlewitz H., Burkner S., 1999, A general approach to disassembly planning and control. Production Planning and Control, 10, 718-726.

Xiong Y., Li G., 2013, The value of dynamic pricing for cores in remanufacturing with backorders. Journal of the Operational Research Society, 64, 1314-1326.

Zhang T., Chu J., Wang X., Liu X., Cui P., 2011, Development pattern and enhancing system of automotive components remanufacturing in China, Resources. Conservation and Recycling, 55, 613-622.

Zikopoulos C., Tagaras G., 2008, On the attractiveness of sorting before disassembly in remanufacturing. IIE Transactions, 40, 313-323.

Örsdemir A., Kemahlioğlu-Ziya E., Parlaktürk A. K. 2014, Competitive quality choice and remanufacturing. Production and Operations Management, 23, 48-64.

Östlin J., 2008, On Remanufacturing System, Analysis and Managing Material Flows and Remanufacturing Processes, Dissertation No. 1192, Linköping University, Linköping, Sweden.

Östlin J., Sundin E., Bjorkman M., 2008, Importance of closed-loop supply chain relationships for product remanufacturing. International Journal of Production Economics, 115, 336-348.

Östlin J., Sundin E, Bjorkman M., 2009, Product life-cycle implications for remanufacturing strategies. Journal of Cleaner Production, 17, 999-1009. 
Appendix 



\section{Appendix A. Questionnaire for "Motives and barriers of the remanufacturing industry in China"}

\section{Dear Sir/Madam:}

This questionnaire is conducted by researchers from Linköping University (Sweden), Tongji University (China) and China Association of Circular Economy, in order to gain knowledge on the present situation of Chinese Remanufacturing industry. With such gained knowledge, we aim to provide suggestions on how to improve the situations of Chinese remanufacturing industry, possible further research will be conducted based on the questionnaire results. Terms used in the questionnaire are explained before the questions in the following page.

The individual data collected through this survey are held anonymous. After the survey, you will receive the results and summary of our investigation of all participating companies.

Your contribution is important for our research and the development of remanufacturing business in China. We really appreciate your help!

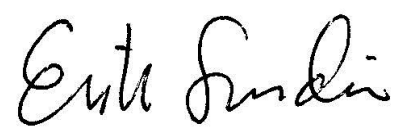

Erik Sundin ${ }^{1}$ (Associate Professor) erik.sundin@liu.se, +4613286601

Shuoguo Wei ${ }^{1 *}$

wei.shuoguo@liu.se, +46764092743

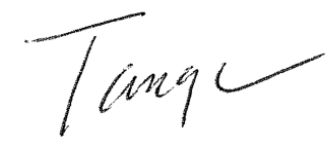

Ou Tang ${ }^{1}$ (Professor)

ou.tang@liu.se, +4613281773

Dongbo Cheng ${ }^{2,3 *}$

cdbbyxl@sohu.com, +8613501789991

${ }^{1}$ Department of Management and Engineering (IEI), Linköping University, 58183, Sweden

${ }^{2}$ School of Management and Engineering, Tongji University, 200092, China

${ }^{3}$ China Association of Circular Economy

"Answered questionnaire can be sent to this Email

\section{Linköping University}
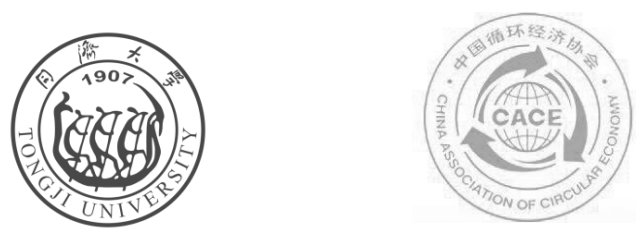


\section{Related Definitions in the Questionnaire}

Remanufacturing - the process of collecting used parts or products, and returning them to goodas-new quality condition by procedures such as, disassembling, cleaning, quality check, repairing and replacing parts, reassembling, testing, etc.

Original Equipment Manufacturer/Remanufacturer - the company remanufactures products of its own brand

Independent Remanufacturer - the company remanufactures products with the brands of other companies

Leasing - the customers lease a physical product. The lease is contracted and often the customer is offered to buy the product at a reduced price at the end of lease time. 


\section{Basic information}

\section{Questionnaire}

1.1) What positions do you hold in your company?
- CEO
$\circ$ Managers

○ Other positions (please specify below)

1.2) What type of remanufacturer is your company?

- Original Equipment Manufacturer/Remanufacturer (OEM/OER)

Independent Remanufacturer (IR)

1.3) In which sector does your company operate in (several options allowed)
- Car parts
- Electronics
- Office
- Military
- Machinery
- Medicine
O Others (please specify below)

1.4) What is your estimated annual production volume now and target volume in the future? Current volume:

Future target volume:

1.5) How much is the estimated annual turnover of your company?
- Less than 1 million RMB
- 1 to 5 million RMB
○ 5 to 10 million RMB
- More than 10 million RMB

1.6) How many employees are there in your company?
- Less than 20
- 20 to 50
- 50 to 100
- 100 to 200
- More than 200

1.7) Where is your company located?
- Northeast China
- Middle China
- South China
- Southwest China

- North China

- East China

- Northwest China

○ Others (please specify below)

1.8) Please fill in your Email or other contacts, in order to receive our survey summary and report: 


\section{About main motives}

2.1) Please rank how important the following motives for remanufacturing are for your company from 1 to 5 where $1=$ Not important at all, 2=Not important, 3=Important, 4=Very important and 5=Extremely important.

- Secure spare parts supply

To secure spare parts supply after the mass production

○ Warranty

$\square 1 \quad \square 2 \quad \square 3 \quad \square 4 \quad \square 5$

To deal with warranty products and decrease warranty costs

- Market share

$\square 1 \quad \square 2 \quad \square 3 \quad \square 4 \quad \square 5$

To increase market share

- Asset and brand protection

$\square 1 \quad \square 2 \quad \square 3 \quad \square 4 \quad \square 5$

To discourage competitors from recovery low-quality products, since they could harm our company brand

○ Customer orientation $\quad \square 1 \quad \square 2 \quad \square 3 \quad \square 4 \quad \square 5$

To satisfy the customer by providing products of reasonable price in a relatively long period

○ Legislation $\quad \square 1 \quad \square 2 \quad \square 3 \quad \square 4 \quad \square 5$

It is required by government legislation to take back the used products

○ Profitability $\quad \square 1 \quad \square 2 \quad \square 3 \quad \square 4 \quad \square 5$

To gain profitability directly from remanufactured products

○ Strategic advantage $\quad \square 1 \quad \square 2 \quad \square 3 \quad \square 4 \quad \square 5$

To be able to offer the customers both new and remanufactured products

○ Competition

To keep competiveness towards our competitors

$\circ$ Subsidies $\quad \square 1 \quad \square 2 \quad \square 3 \quad \square 4 \quad \square 5$

The government provides tax subsidies and other financial support

○ Environmental and ethical responsibility $\quad \square 1 \quad \square 2 \quad \square 3 \quad \square 4 \quad \square 5$

To improve the environment and 'green image' of our company

○ Others you think important (please specify below) $\quad \square 1 \quad \square 2 \quad \square 3 \quad \square 4 \quad \square 5$

2.2) Do you expect that the above motivations you have chosen will keep the same, being stronger, or they will be weaker in the coming 5-10 years?

$\circ$ Secure spare parts supply $\quad \square$ weaker $\quad \square$ same $\quad \square$ stronger

$\circ$ Warranty $\square$ weaker $\square$ same $\square$ stronger

○ Market share $\quad \square$ weaker $\quad \square$ same $\quad \square$ stronger

- Asset and Brand protection $\quad \square$ weaker $\quad \square$ same $\quad \square$ stronger

○ Customer orientation $\quad \square$ weaker $\square$ same $\quad \square$ stronger

○ Legislation $\square$ weaker $\square$ same $\square$ stronger 

○ Profitability
$\square$ weaker
$\square$ same
$\square$ stronger
- Strategic advantage
$\square$ weaker $\square$ same
$\square$ stronger
- Competition
$\square$ weaker $\square$ same
$\square$ stronger
- Subsidies
$\square$ weaker
$\square$ same
$\square$ stronger
- Environmental and ethical responsibility
$\square$ weaker
$\square$ same
$\square$ stronger
- Others motives you specified above
$\square$ weaker
$\square$ same
$\square$ stronger

\section{About main obstacles}

3.1) Please rank how seriously of the following obstacles have limited the profitability of your company from 1 to 5 where $1=$ Not seriously at all, 2=Not seriously, $3=$ Seriously, 4=Very seriously and 5=Extremely seriously.

○ Core volume

$\square 1 \quad \square 2 \quad \square 3 \quad \square 4 \quad \square 5$

There are not enough cores to meet the demand.

- Core quality

The quality of collected cores is not good enough.

$\square 1 \quad \square 2 \quad \square 3 \quad \square 4 \quad \square 5$

- Customer recognition

$\square 1 \quad \square 2 \quad \square 3 \quad \square 4 \quad \square 5$

The customers don't consider the remanufactured products have enough quality.

$\circ$ Lack of sales channels $\quad \square 1 \quad \square 2 \quad \square 3 \quad \square 4 \quad \square 5$ The sales channels of us are not enough or don't work very well.

$\circ$ Legislation restrictions $\quad \square 1 \quad \square 2 \quad \square 3 \quad \square 4 \quad \square 5$ The legislation/regulations prevent the potential profitability of our products.

○ Lack of technology $\quad \square 1 \quad \square 2 \quad \square 3 \quad \square 4 \quad \square 5$ The remanufacturing technology is very difficult for us.

○ Lack of product knowledge $\quad \square 1 \quad \square 2 \quad \square 3 \quad \square 4 \quad \square 5$

The knowledge of the products is too low to repair them.

○ High labor cost $\quad \square 1 \quad \square 2 \quad \square 3 \quad \square 4 \quad \square 5$

The labor cost in our region is too high.

- Other obstacles you think important (please specify below)

3.2) Do you expect that the above obstacles you have ranked will be worse, the same, or they will be improved in the coming 5-10 years?
- Core volume
$\square$ worse
$\square$ same
$\square$ improve
- Core quality
$\square$ worse $\quad \square$ same
$\square$ improve
- Customer recognition
$\square$ worse $\square$ same
$\square$ improve
- Lack of sales channels
$\square$ worse
$\square$ same
$\square$ improve
- Legislation restrictions
$\square$ worse
$\square$ same
$\square$ improve
- Lack of technology
$\square$ worse
$\square$ same
$\square$ improve 


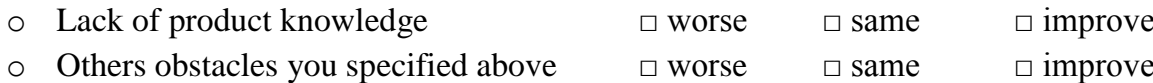

\section{About profitability}

4.1) In your company, is it more profitable to sell remanufactured products than manufacturing new products?

○ Yes

○ No

4.2) In your company, are people afraid that the remanufactured products may take the profit of new products away, thus harm the total profitability of the company?

○ Yes

$\circ$ No

\section{About subsidies}

5.1) Does your company get subsidies (tax reduction, loan, etc.) from government policy?

- Yes

○ No

5.2) Is remanufacturing still profitable without government subsidies?

○ Yes

○ No

○ Not sure

5.3) Will you still keep remanufacturing if such subsidies are cancelled?

○ Yes

○ No

- Not sure

\section{About core collection}

6.1) Which of the following best describes the supply chain relationship of your company?

○ Ownership-based

The product is owned by the manufacturer and operated by the customer, as for example in a rental, lease or product-service offer.

○ Service contract

This type of relationship is based on a service contract between a manufacturer and a customer that includes remanufacturing.

- Direct-order

The customer returns the used product to the remanufacturer, the product is remanufactured and the customer gets the same product back (if it is possible to perform a remanufacturing operation). 
- Deposit-based

When the customers buy a remanufactured product, they are obligated to return a similar used product, thus also acting as a supplier to the remanufacturer.

○ Credit-based

When the customers return a used product they receive a specific number of credits for the returned product. These credits are then used as a discount when buying a remanufactured product.

○ Buy-back

The remanufacturer simply buys the wanted used products from a supplier that can be the end user, a scrap yard or similar, or a core dealer.

○ Voluntary-based

The supplier gives the used products to the remanufacturer. The supplier can also be a customer but do not have to be.

Others (please specify below)

6.2) Do you have to compete with other core collectors?

○ Yes

$\circ$ No

6.3) If 'yes' to 6.2), who are your main competitors for collecting cores?

- Third party core collector

- Repair industry

○ Other remanufacturers

- Others (please specify below)

\section{About labor cost and technology}

7.1) Is it hard to hire the labor with the proper knowledge and skills for remanufacturing?

○ Yes

○ No

7.2) Is it necessary to train the workers before they are able to work?

- Yes

- No

7.3) If 'yes' to 7.2), how long will be the training on average?

7.4) What are the most difficult technologies (process steps) for your company?

7.5) What are the most time consuming technologies (process steps) for your company? 
7.6) Could your product be adapted to remanufacturing (e.g. by Design-forremanufacturing)?
- Yes
○ No

7.7) If 'yes' to 7.6), in what way could the product be more adapted?

\section{About legislation}

8.1) Do you consider government legislation to have limited your remanufacturing ability?

- Yes

○ No

8.2) If 'yes' to 8.1), please specify in what way the legislation limited the remanufacturing business

\section{About market}

9.1) How do you expect about the market of your remanufactured products in the future 5-10 years?
○ Strong Growth
- Slow but Steady Growth
- Keep the same
- Decrease

9.2) How do you sell the remanufactured products?
○ By service channel
- By leasing to customers
- By contracted OEM
- By internet website (e.g. taobao, alibaba, etc.)
- Others (please specify below)

9.3) Who are your main competitors on market?
- Repair industry
- Independent remanufacturers
- Other OEM remanufacturers
- Others you think important (please specify below)

9.4) Do the consumers differentiate the remanufactured products and new manufactured products in your case? 
○ Yes

o No

- Not sure

9.5) To which quality does your company remanufacture?

- Same as manufactured products

○ Worse than manufactured products

9.6) Which warranty do you give for the remanufactured products?

- Same as manufactured products

- Shorter than manufactured products

9.7) How much percentage is the price of your remanufactured products compared with new manufactured products?

- Much lower than new manufactured products $(<40 \%)$

- About half the price of new manufactured products (40\%-60\%)

○ Lower than new manufactured products $(60 \%-80 \%)$

- A little lower than new manufactured products

- The same

The questionnaire ends in this page, thanks again for your participation! 



\section{Appendix B. The author's contributions to the appended papers}

For this doctoral dissertation "Core Acquisition Management in Remanufacturing - Current Status and Modeling Techniques", the author Shuoguo Wei's contribution in each appended paper is summarized below.

Paper 1

Wei S., Tang O., Sundin E., 2014, Core (product) Acquisition Management for remanufacturing: a review, submitted to Journal of Remanufacturing.

In this paper Wei S. takes the leading role in initiating the research idea, collecting data, data analysis and writing.

Paper 2

Wei S., Cheng D., Sundin E., Tang O., 2014, Motives and barriers of the remanufacturing industry in China, submitted to Journal of Cleaner Production, under second round review.

In this paper Wei S. takes the leading role in initiating the research idea, questionnaire design, data analysis and writing.

\section{Paper 3}

Wei S., Tang O., 2014, Managing cores for remanufacturing during the product life cycle, submitted to Annuals of Operations Research.

In this paper the initial research idea is developed by both authors. Then Wei S. takes the leading role in developing models, computing the examples, analyzing results and writing the manuscript.

\section{Paper 4}

Wei S., Tang O., 2014, Real option approach to evaluate cores for remanufacturing in service markets, International Journal of Production research, accepted, DOI:10.1080/00207543.2014. 939243.

In this paper the research idea is initiated by the coauthor. Wei S. then takes a leading role in developing the models, analyzing the numerical results and writing the manuscript.

\section{Paper 5}

Wei S., Tang O., Liu W., 2014, Refund policies for cores with quality variation in OEM remanufacturing, International Journal of Production Economics, accepted, DOI:10.1016/j.ijpe.2014. 12.006

In this paper Wei S. takes a leading role in initializing the research idea, developing the models, analyzing the results and writing the manuscript.

\section{Paper 6}

Wei S., Tang O., 2014, Refund polices for core collecting regarding the customers' responses, submitted to International Journal of Production Economics.

In this paper Wei S. takes a leading role in initializing the research idea, developing the mathematical models, analyzing the results and writing the manuscript. 

Appendix C. Appended papers 



\section{Papers}

The articles associated with this thesis have been removed for copyright reasons. For more details about these see:

http://urn.kb.se/resolve?urn=urn:nbn:se:liu:diva-113251 